\title{
Discovery of Novel multi-target Indole-based Derivatives as Potent and Selective Inhibitors of Chikungunya Virus Replication
}

\author{
Maria Scuotto\#a, Rana Abdelnabi \#, Selene Collarile ${ }^{a \#, ~ C h i a r a ~ S c h i r a l d i ~}{ }^{a}$, \\ Leen Delang ${ }^{b}$, Antonio Massad, Salvatore Ferlac, Andrea Brancale ${ }^{c}$, \\ Pieter Leyssen ${ }^{b}$, Johan Neyts ${ }^{b}$, Rosanna Filosa $a^{a^{*}}$ \\ ${ }^{a}$ Department of Experimental Medicine, University of Naples, Via Costantinopoli, 16, 80138 \\ Naples, Italy \\ ${ }^{b}$ KU Leuven - University of Leuven, Department of Microbiology and Immunology, Rega \\ Institute for Medical Research, Laboratory of Virology and Chemotherapy, B-3000 Leuven, \\ Belgium
}

${ }^{c}$ School of Pharmacy and Pharmaceutical Sciences, Cardiff University, King Edward VII Avenue, Cardiff CF10 3NB, UK

\section{Corresponding author:}

Rosanna Filosa, Department of Experimental Medicine, Second University of Naples, Via Costantinopoli, 16 80138 Naples, Italy; Phone:0815667663; e-mail: rosanna.filosa@unina2.it

\# These authors contribute equally 


\begin{abstract}
We recently identified indole derivatives (IIIe and IIIf) with anti-chikungunya virus (CHIKV) activities at lower micro molar concentrations and a selective index of inhibition higher than the lead compound Arbidol. Here we highlight new structural information for the optimization of the previously identified lead compounds that contain the indole chemical core. Based on the structural data, a series of indole derivatives was synthesized and tested for their antiviral activity against chikungunya virus in Vero cell culture by a CPE reduction assay. Systematic optimization of the lead compounds resulted in tert-butyl-5-hydroxy-1-methyl-2-(2trifluoromethysulfynyl)methyl)-indole-3-carboxilate derivative IIc with a 10-fold improved antiCHIKV inhibitory activity $\left(\mathrm{EC}_{50}=6.5 \pm 1 \mu \mathrm{M}\right)$ as compared to Arbidol demonstrating a potent, selective and specific inhibition of CHIKV replication with only a moderate cell protective effect against other related alphaviruses. The reported computational insights, together with the accessible synthetic procedure, pave the road towards the design of novel synthetic derivatives with enhanced anti-viral activities.
\end{abstract}




\section{Introduction}

Chikungunya virus (CHIKV) is a re-emerging arbovirus that belongs to the genus alphavirus of the Togaviridae family. An infection with this virus results in chikungunya fever (CHIKF), with symptoms starting generally 4-7 days after the mosquito bite. The infection is occurring in two phases, the first being acute, characterized by fever and joint pains, while the second stage is persistent (chronic), causing disabling polyarthritis.[1] Although during the mid twentieth century epidemiological emergency of CHIKV was limited to Africa, the virus spread to India and South-East Asia starting from 2004, causing large scale epidemics. After that, CHIKV transmission was also reported for the first time in Europe. In December 2013, the first local transmission was observed in the Americas, resulting in over 1,5 million infected patients. To date, despite its serious nature, no drugs have been approved for the treatment of CHIKV, but promising in vitro results have been obtained with Arbidol (ARB), a drug that already has been licensed for the treatment of influenza A and B virus infections in Russia and China.[2]

So far, Arbidol has shown a wide range of activity against many RNA, DNA, enveloped and non enveloped viruses[3] and recently also against CHIKV replication in immortalized Vero cells or primary human fibroblasts (MRC-5 lung cells) (EC50 $<10 \mu \mathrm{g} / \mathrm{mL})$.[4] The exact mechanism of the anti-CHIKV activity of Arbidol is not entirely understood. A previously reported study demonstrated its involvement in blocking the early stages of the viral life cycle.[4] Moreover, a single mutation from glycine to arginine in the E2 protein (G407R) generated an Arbidol resistant-CHIKV mutant giving an important insight of the mechanism of action. Gly407 is localised in the "wings" insertion of domain A, a region that could be involved in the interaction with different receptors.[4] 
Starting from Arbidol we identified several indole derivatives that inhibit CHIKV replication in phenotypic virus cell-based assays. [5] We demonstrated that the combined effect of an increased steric hindrance on the thiophenol ring and the replacement of an ethyl group in position 2 with a tert-butyl were necessary to improve the in vitro antiviral potency of this class of compounds. Moreover, oxidation of the sulfur atom in the linker led to a reduced cellular toxicity while preserving or increasing the antiviral activity. In particular, two new compounds IIIe and IIIf (Chart 1) had an antiviral activity higher than the other derivatives $\left(\mathrm{EC}_{50} 30 \mu \mathrm{M}-32 \mu \mathrm{M}\right)$ with a selective index of inhibition 13.2 and 14.6 respectively, which is higher than Arbidol.

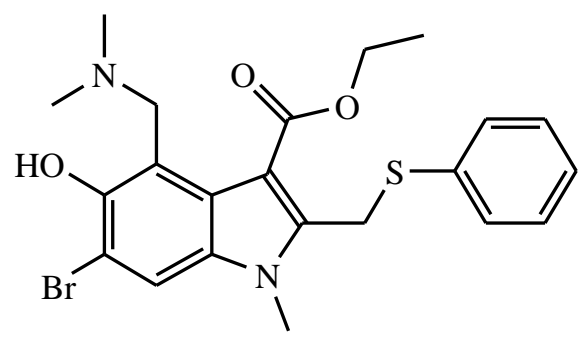

Arbidol<smiles>CCCCOC(=O)c1c(CS(=O)c2c(Cl)cccc2Cl)n(C)c2ccc(CO)cc12</smiles>

$\mathrm{EC}_{50}: 30 \pm 4 \quad \mathrm{CC}_{50}: 397 \pm 24$

SI: 13.2<smiles>CCCCOC(=O)c1c(CS(=O)c2ccccc2C(F)(F)F)n(C)c2ccc(CO)cc12</smiles>

$\mathrm{EC}_{50}: 32 \pm 1.1 \quad \mathrm{CC}_{50}:>468$

SI: 14.6

\section{Chart1}


Here we describe the optimization of the previously identified indole derivatives based on novel structural information using the crystal structure of the CHIKV glycoprotein complex and the characterization of the mechanism of action of the anti-CHIKV activity of this series of compounds.

\section{Results and discussion}

\subsection{Docking studies}

In order to elucidate the potential binding pocket of Arbidol in the E2 viral protein and to suggest a hypothetical binding mode for the new indole derivatives, different molecular modelling studies were performed. The E2 unit of the crystal structure of the mature E3-E2-E1 glycoprotein complex (PDB ID: 3N42) was used in the simulations (Gly407 corresponds to Gly82 in the crystal structure). [6] Using the site finder tool in MOE 2015.4, two potential binding sites in proximity of Gly82 were identified (site 1 and site 2; Figure 1).

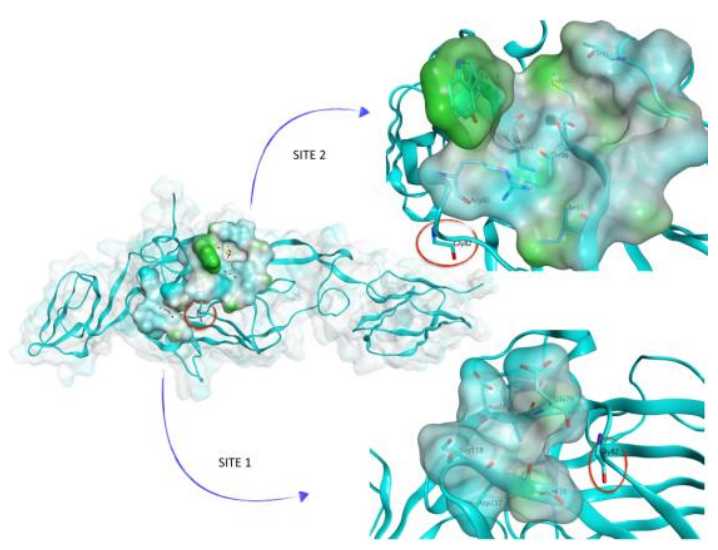

Figure 1 
Docking studies of Arbidol on site 1, the closest site to Gly82, gave inconsistent results, indicating that this small hydrophilic and shallow pocket is probably not the binding site for Arbidol (Figure 2b). Site 2 consists of a more hydrophobic and well-defined pocket formed by Trp64, Arg80, Met97, Thr96 and Thr160 (Figure 2a). Gly82 is not directly involved in site 2 formation but it should be noted that this residue is located in a very flexible loop and it can be speculated that a substitution to arginine, a significantly bigger residue, could change the loop conformation affecting the overall architecture of the proposed site 2. Moreover, Arbidol has been reported to interact with tryptophan-rich molecules. [7]

Taking this into account, site 2 was considered the most relevant for our docking simulations. The results showed that Arbidol occupies the binding site inserting the ethyl ester group and the thiophenol deep in the pocket, whereas the dimethyl amino moiety and the hydroxyl group are more solvent exposed. Moreover, contacts between the ethyl ester and Trp64 and Arg80 are observed.

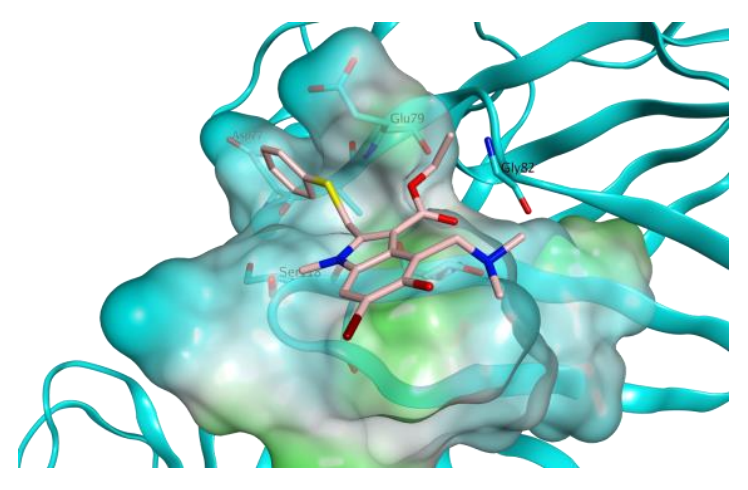

Figure 2a 


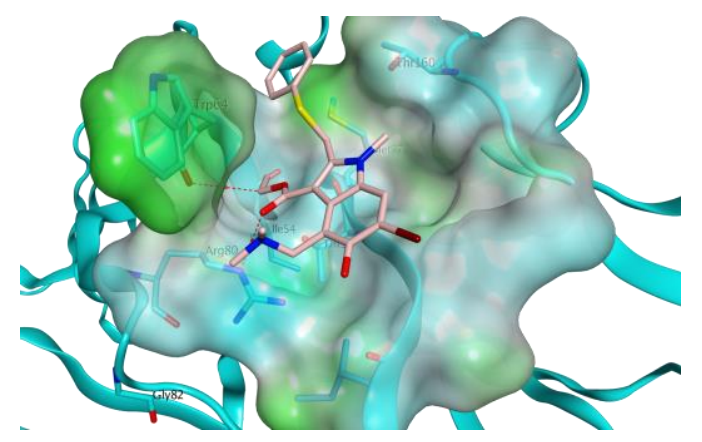

Figure 2b

A different binding mode seems to be prevalent for the previously reported derivatives IIIe and IIIf. In this case, the presence of the bulkier t-butyl ester and the differently substituted thiophenols do not allow the same orientation as Arbidol. The indole ring of these derivatives sits deeper in the active site, in proximity of Trp64, while the differently substituted thiophenol occupies the more solvent exposed portion of the site, the same occupied by the indole ring of Arbidol. Finally, as shown in Figure 3a and 3b, the t-butyl group of compound IIIe and IIIf occupies a small hydrophobic sub-pocket, formed by Thr160 and Thr96, possibly increasing the binding affinity. This correlates well with the increased biological activity often observed with the analogues that contain this ester. 


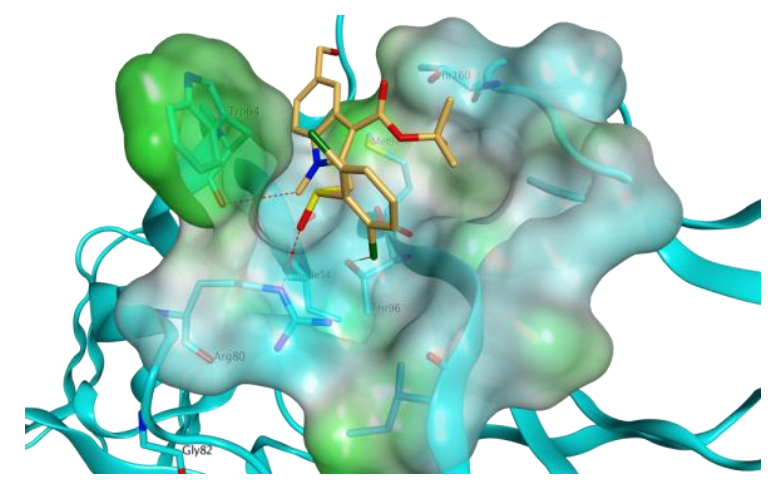

Figure 3a

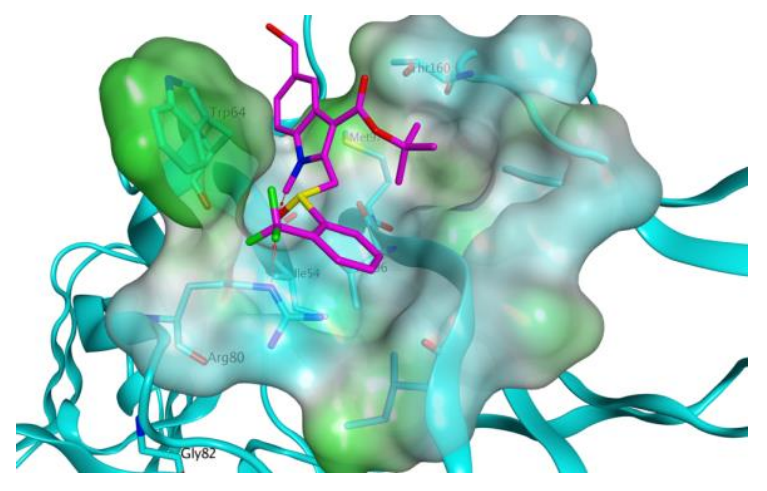

Figure 3b 
Based on the above results, the design and synthesis of indole based molecules as new potential entry inhibitors was continued. In particular, from a structural point of view, the synthesized molecules can be assigned to three main groups:

I) Indole t-butylester derivatives with the replacement of bromine in position 5 and phenol group in position 4 as the lead Arbidol,

II) The most interesting compounds of series I were converted again into corresponding sulfoxides to confirm oxidation of sulfide to lead a reduction in cellular toxicity while preserving or increasing antiviral properties.

III) Selected derivatives from the two previous series were analyzed regarding the simultaneously introduction of amine group and thiol oxidation.

We decided to use the same structural decorations in each subset of compounds in order to enable the identification of structural elements required to increase the antiviral effects and to confirm that the replacement of a hydroxyl group in position 5 is necessary to improve the in vitro antiviral potency of this class of compounds.

\subsection{Chemistry}

Indole derivatives Ia-g and IIa-f were synthesized according to Scheme 1. The synthesis of 5hydroxy-indole derivatives started from commercially available tert-butyl acetoacetate $\mathbf{3}$, which was easily converted into imine giving compound $\mathbf{4}$ in high yields. It was reacted with $1,4-$ benzoquinone in presence of catalytic amount of $\mathrm{ZnI}_{2}$ as described to Nenitzescu reaction giving intermediate 5. After protection of hydroxyl group using acetic anhydride and pyridine, Nalkylation with iodomethane was carried out by a modified Kikugawa's procedure [10] to afford compound 6 in quantitative yields. Treatment with 1 equiv of NBS allowed to obtain selective allylic brominated [11] compound 7 and subsequent treatment with several substituted 
thiophenols in methanol provided esters Ia-g. The synthesis of sulfoxides IIa-f was obtained starting from Ia-f derivatives, that were oxidized using $77 \%$ meta chloroperbenzoic acid in $\mathrm{CH}_{2} \mathrm{Cl}_{2}$ at room temperature in very short time $(5 \mathrm{~min})$. Reaction with $\mathrm{N}, \mathrm{N}, \mathrm{N}^{\prime}, \mathrm{N}^{\prime}-$ Tetramethylethylenediamine and acetic acid yielded the final compounds IV a-d.
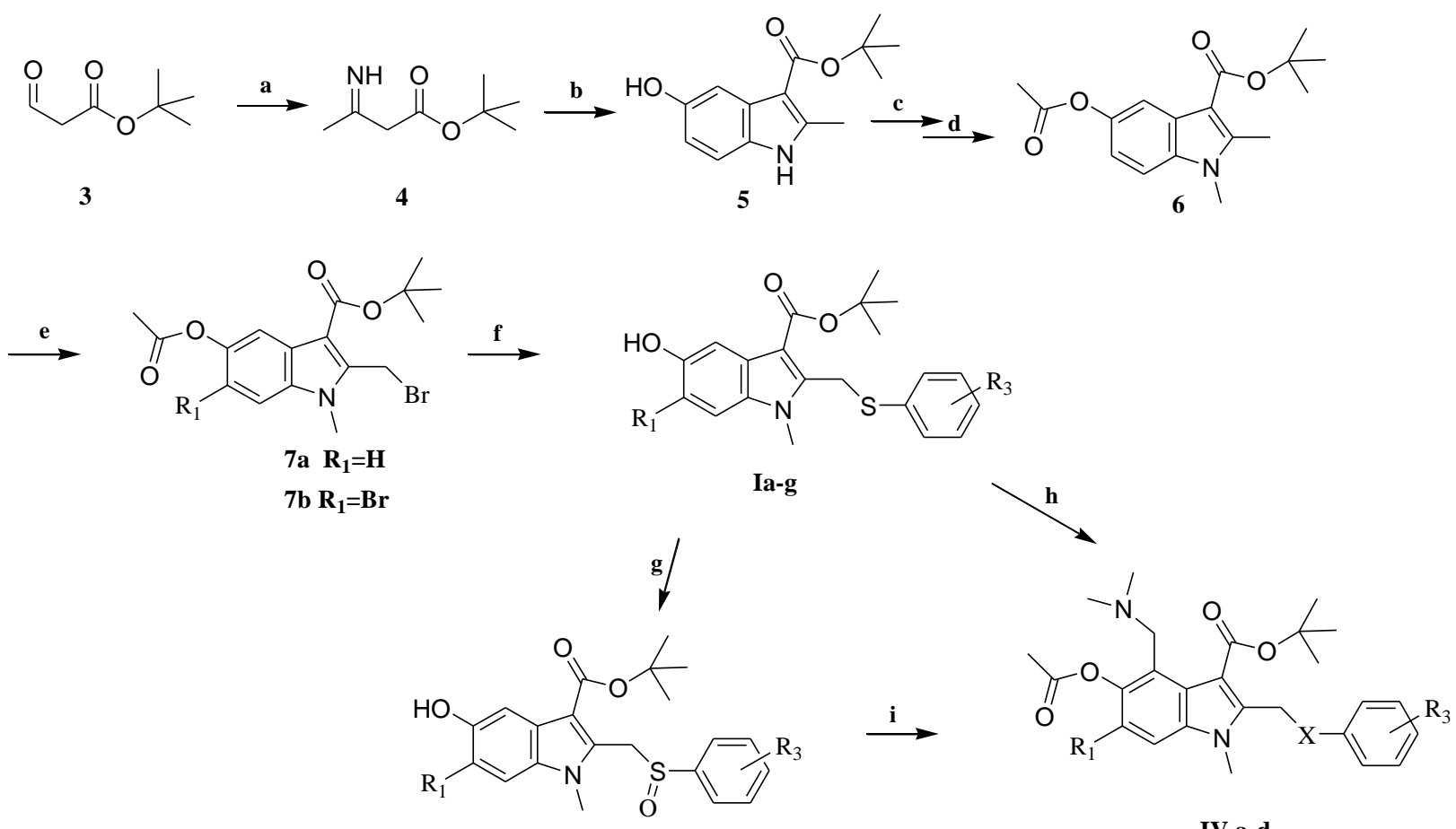

IIa-f

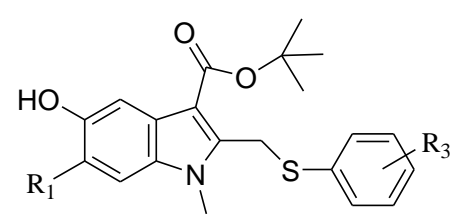

Ia-g

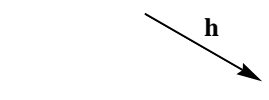

IV a-d

Scheme 1 


\subsection{Effect of Arbidol derivatives on the cytopathogenic effect (CPE) induced by CHIKV}

All synthesized compounds (Ia-g, IIa-f, IVa-d) were evaluated for cytotoxicity and antiCHIKV activity in Vero cells, more specifically for their ability to inhibit the cytopathogenic effect (CPE) induced by the virus. The results are summarized in Tables 1-3. Regarding the $\mathbf{t}-$ butylseries, (Series I) it is worth to note that the replacement of the methylhydroxyl group in position 5 with a hydroxyl group resulted in compounds with increased antiviral activity even though this was associated with significant cytotoxicity $\left(\mathrm{EC}_{50}\right.$ values ranging from 2.9 to 4.8 $\mu \mathrm{M})$. As previously shown the presence of an electron-withdrawing substituent (such as fluorine, trifluoromethyl or chlorine) in the para position of the thiophenol ring yields molecules with an antiviral effect, more pronounced than that of Arbidol. On the other hand, when a trifluoromethyl group or chorine was introduced in orto position, only a weak improvement in antiviral effect was observed. Analysis of the structure-activity relationships revealed that the bromine on the indole backbone is not essential for the inhibitory antiviral activity (Id $v s$ Ic and $\mathbf{I g} v s \mathbf{I b}$ ). Derivatives with the lowest $\mathrm{EC}_{50}$ values were converted into their corresponding sulfoxides (Series II), keeping in mind that the oxidation of the sulfide is expected to reduce the cellular toxicity by reasons previously mentioned. The results are summarized in Table $\mathbf{2}$. The oxidation to sulfoxides significantly reduced the cytotoxicity of all compounds, with improved antiviral activity with only slightly higher $\mathrm{EC}_{50}$ values for IIa. Moreover, it can be observed that all amine compounds were less active even in the case of the corresponding bromide derivatives (Table III). Based on these data, compound IIc emerged as a very interesting compound, as it showed a better therapeutic index compared to Arbidol and the previous analogs with a 10-fold improved anti-CHIKV inhibitory activity $\left(\mathrm{EC}_{50}=6.5 \pm 1 \mu \mathrm{M}\right)$. Hence, it was selected together with the 
previous described trifluoromethyl derivative IIIf for further experiments to characterize the anti-CHIKV activity. 


\begin{tabular}{|c|c|c|c|c|c|}
\hline \multicolumn{6}{|c|}{ Series I } \\
\hline & & \multicolumn{4}{|c|}{ CHIKV inhibition } \\
\hline Cpd & $\mathbf{R}_{1}$ & $\mathrm{R}_{2}$ & ${ }^{\mathrm{a}} \mathbf{C} \mathbf{C}_{50}(\boldsymbol{\mu M})$ & ${ }^{\mathrm{b}} \mathbf{E} \mathbf{C}_{50}(\boldsymbol{\mu} \mathbf{M})$ & $\mathbf{S I}^{\mathbf{c}}$ \\
\hline Ia & $\mathrm{H}$ & $4-\mathrm{CF}_{3}$ & 11 & 3.6 & 3.1 \\
\hline Ib & $\mathrm{H}$ & $2,6-\mathrm{Cl}$ & 7.8 & 2.9 & 2.7 \\
\hline Ic & $\mathrm{H}$ & $2-\mathrm{CF}_{3}$ & 19 & 3.4 & 4.1 \\
\hline Id & $\mathrm{Br}$ & $2-\mathrm{CF}_{3}$ & 26 & 9.6 & 2.7 \\
\hline Ie & $\mathrm{H}$ & $4-\mathrm{F}$ & 11 & 4.5 & 3.2 \\
\hline If & $\mathrm{H}$ & $4-\mathrm{Cl}$ & 15 & 4.8 & 3.2 \\
\hline Ig & $\mathrm{Br}$ & $2,6-\mathrm{Cl}$ & 13 & 5.7 & 2.3 \\
\hline Arbidol & & & $161 \pm 18$ & $35 \pm 8$ & 4.6 \\
\hline
\end{tabular}

Table 1 


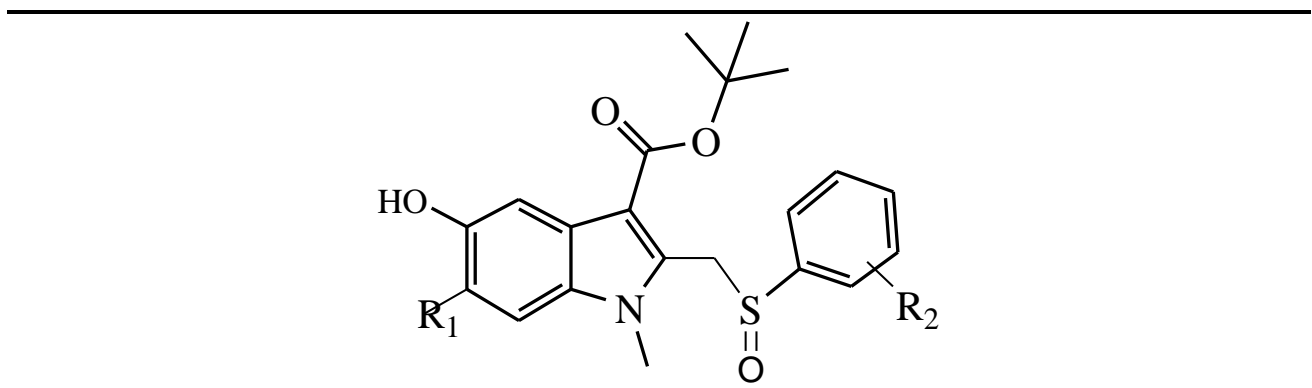

Series II

\begin{tabular}{|c|c|c|c|c|c|}
\hline & & \multicolumn{4}{|c|}{ CHIKV inhibition } \\
\hline Cpd & $\mathbf{R}_{\mathbf{1}}$ & $\mathbf{R}_{2}$ & ${ }^{\mathrm{a}} \mathbf{C} \mathbf{C}_{50}(\boldsymbol{\mu} \mathbf{M})$ & ${ }^{\mathrm{b}} \mathbf{E} \mathbf{C}_{50}(\boldsymbol{\mu M})$ & $\mathbf{S I}^{\mathbf{c}}$ \\
\hline IIa & $\mathrm{H}$ & $4-\mathrm{CF}_{3}$ & 24 & 13 & 1.9 \\
\hline IIb & $\mathrm{H}$ & $2,6-\mathrm{Cl}$ & 151 & 20 & 7.6 \\
\hline IIc & $\mathrm{H}$ & $2-\mathrm{CF}_{3}$ & 156 & $6.5 \pm 1$ & 22 \\
\hline IId & $\mathrm{Br}$ & $2-\mathrm{CF}_{3}$ & 26 & 9.6 & 2.7 \\
\hline IIe & $\mathrm{H}$ & $4-\mathrm{F}$ & $>100$ & $17 \pm 3$ & $>5.7$ \\
\hline IIf & $\mathrm{H}$ & $4-\mathrm{Cl}$ & 93 & $8.2 \pm 6$ & 11 \\
\hline Arbidol & & & $161 \pm 18$ & $35 \pm 8$ & 4.6 \\
\hline
\end{tabular}

Table 2 


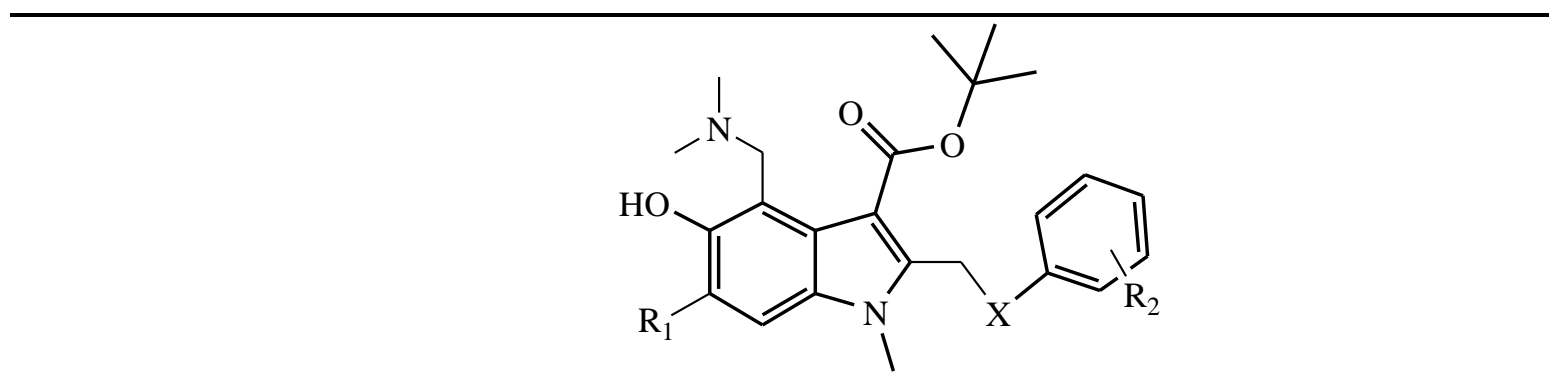

Series IV

\begin{tabular}{|c|c|c|c|c|c|c|}
\hline & & & \multicolumn{4}{|c|}{ CHIKV inhibition } \\
\hline Cpd & $\mathbf{R}_{1}$ & $\mathbf{R}_{\mathbf{2}}$ & $\mathbf{X}$ & ${ }^{\mathrm{a}} \mathbf{C C}_{50}(\boldsymbol{\mu M})$ & ${ }^{\mathrm{b}} \mathbf{E} \mathbf{C}_{50}(\mu \mathbf{M})$ & $\mathbf{S I}^{\mathbf{c}}$ \\
\hline IVa & $\mathrm{Br}$ & $2,6-\mathrm{Cl}$ & $-\mathrm{S}$ & 17 & $\geq 17$ & - \\
\hline IVb & $\mathrm{H}$ & $2,6-\mathrm{Cl}$ & $-\mathrm{S}=\mathrm{O}$ & 9.2 & 4.1 & 2.2 \\
\hline IVc & $\mathrm{H}$ & $2-\mathrm{CF}_{3}$ & $-\mathrm{S}=\mathrm{O}$ & 66 & 22 & 3 \\
\hline IVd & $\mathrm{Br}$ & $2-\mathrm{CF}_{3}$ & $-\mathrm{S}=\mathrm{O}$ & 56 & 12 & 4.6 \\
\hline Arbidol & & & & $161 \pm 18$ & $35 \pm 8$ & 4.6 \\
\hline
\end{tabular}

Table 3 


\subsection{Virus yield assay}

To evaluate the direct inhibitory effect of IIc on CHIKV replication, a virus yield assay was performed and compared with the most active compound of the precedent library IIIf. Interestingly, IIc reduced in a dose-dependent manner both viral RNA levels as well as the production of infectious virus particles (Figure 4, Table 4) and thus can be considered as a selective inhibitor of CHIKV replication and not only a cell-protective compound. On the other hand, the compound showed only moderate antiviral activity against related alphaviruses Semliki Forest virus and Sindbis virus.

\begin{tabular}{|c|c|c|c|c|}
\hline \multirow[t]{2}{*}{ Compound } & \multirow{2}{*}{$\mathrm{CC}_{50} \pm \mathrm{SD}(\mu \mathrm{M})$} & \multicolumn{3}{|c|}{$\mathrm{EC}_{50} \pm \mathrm{SD}(\mu \mathrm{M})$} \\
\hline & & CHIKV & SFV & SINV \\
\hline IIc & $156 \pm 4$ & $\begin{array}{l}6.5 \pm 1^{\mathrm{a}} \\
1 \pm 0.2^{\mathrm{b}} \\
1 \pm 0.1^{\mathrm{c}}\end{array}$ & $33 \pm 2^{\mathrm{a}}$ & $20 \pm 1^{\mathrm{a}}$ \\
\hline IIIf & $>468^{6}$ & $\begin{array}{c}28 \pm 4^{\mathrm{a}} \\
9 \pm 3^{\mathrm{b}} \\
10 \pm 2^{\mathrm{c}}\end{array}$ & $128 \pm 35^{\mathrm{a}}$ & $96 \pm 19^{\mathrm{a}}$ \\
\hline Arbidol & $161 \pm 18^{6}$ & $35 \pm 7^{\mathrm{a}}$ & ND & ND \\
\hline
\end{tabular}

a) CPE reduction assay, b) RT-qPCR or c) titration assay. ND: not determined

Table 4 
A

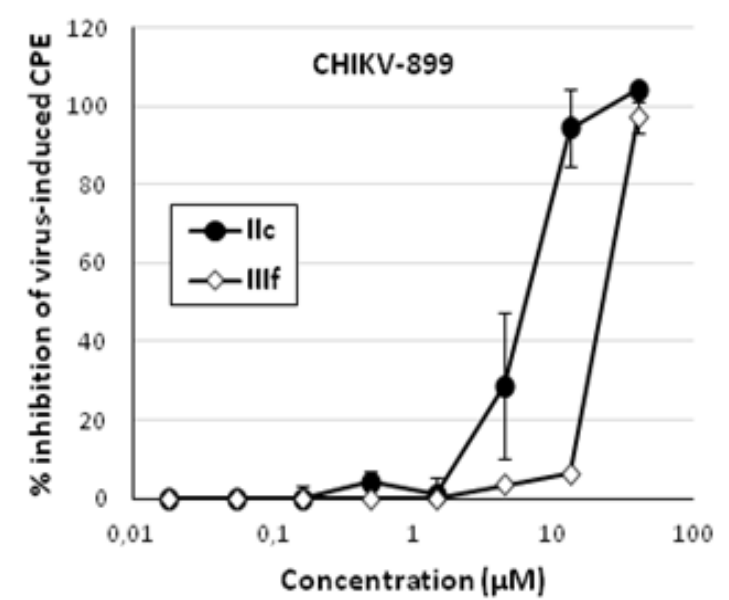

B

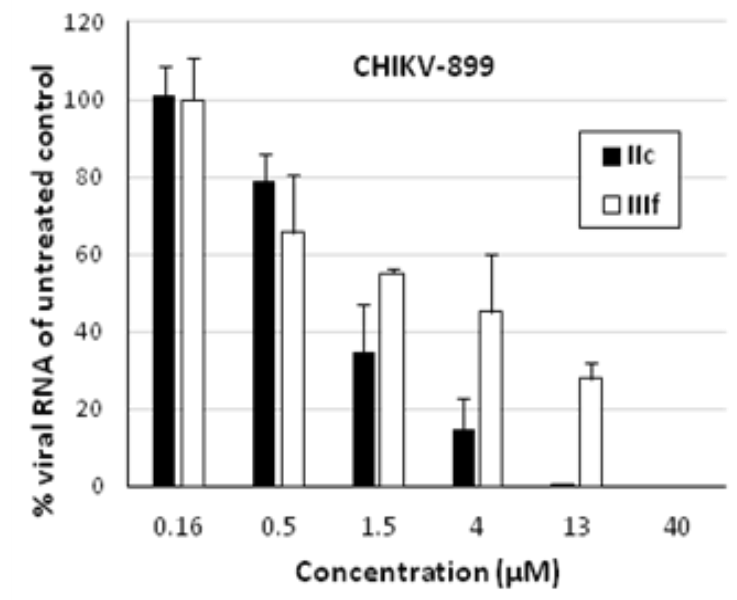

C

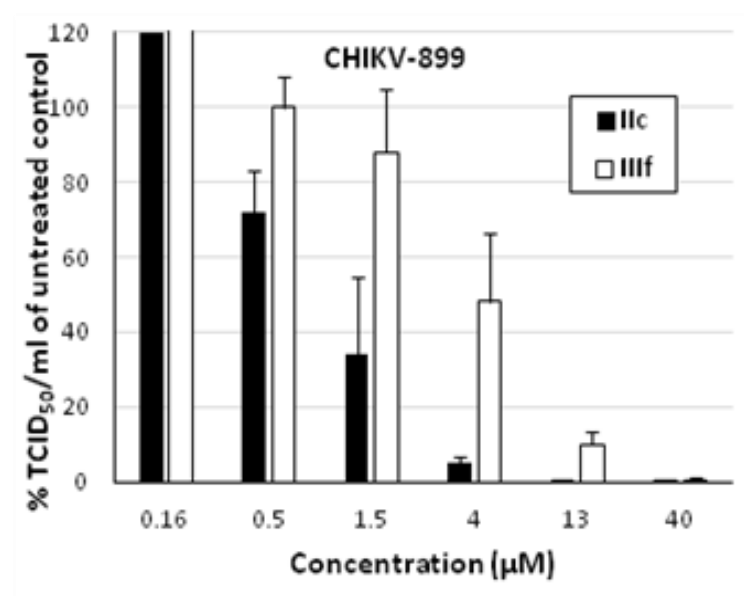

Fig.4 


\subsection{CHIKVpp assay}

The activity of IIc and IIIf was further evaluated in an entry assay using CHIKV pseudoparticles (CHIKVpp). CHIKVpp are lentiviral vectors carrying CHIKV glycoproteins on the exterior and a luciferase reporter gene inside the vesicles and are thus ideally suited to study CHIKV entry independently from post entry steps in the viral life cycle. BGM cells were treated with the compound after which they were exposed to the appropriate dilution of CHIKVpp. After 3 days, the intracellular luciferase signal was measured, which is proportionate to the amount of CHIKVpp that were able to enter the cells in the presence of the compound. Surprisingly, IIc was $\sim 6$-fold less potent than Arbidol in the inhibition of CHIKVpp entry into BGM cells even though IIc is a more potent inhibitor of CHIKV replication than Arbidol (Figure 5a, Table 5), suggesting that IIc may have a different mechanism of action.

\begin{tabular}{ccc}
\hline Compound & $\mathbf{C C}_{\mathbf{5 0}} \pm \mathbf{S D}(\boldsymbol{\mu M})$ & $\mathbf{E C}_{50} \pm \mathbf{S D}(\boldsymbol{\mu M})$ \\
\hline IIc & $50 \pm 5$ & $27 \pm 1.6$ \\
\hline IIIf & $>60$ & $36 \pm 0.9$ \\
\hline Arbidol & $>60$ & $4.4 \pm 1.2$ \\
\hline
\end{tabular}

Table 5 


\subsection{Time of addition assay}

In a time of addition assay, the compound was added at different time points before and after infection to determine at which time point in the viral life cycle it loses its activity and this in parallel with reference compounds with known mechanism of action. IIc inhibited CHIKV replication at a post-entry step as it showed good inhibition of CHIKV replication even when added to cells up to $8 \mathrm{~h}$ post infection. In contrast, Arbidol is only able to inhibit CHIKV replication with more than $50 \%$ when added before or $2 \mathrm{~h}$ after infection (Figure $\mathbf{5 b}$ ). 
A

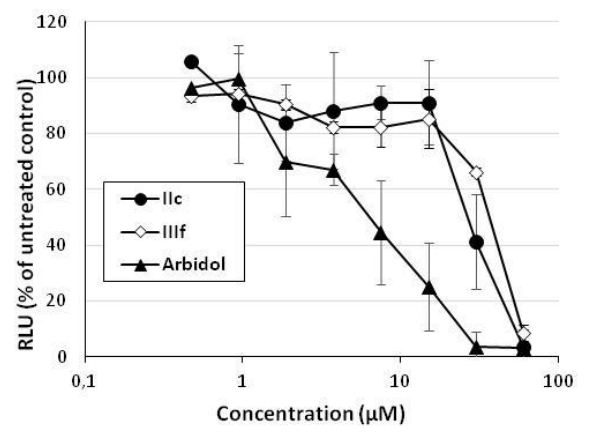

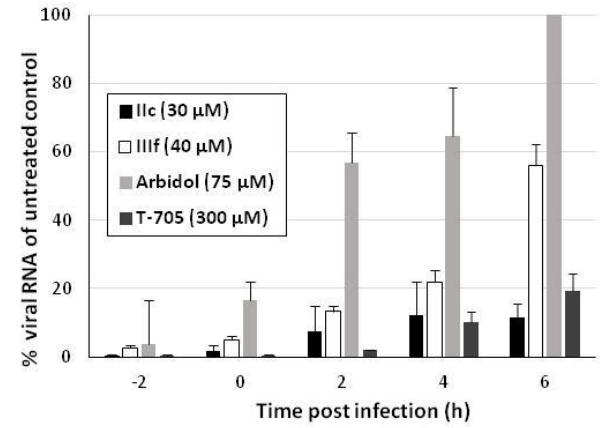

Fig.5 


\subsection{Docking studies II}

Following our previous molecular docking simulations, the same studies on series I and II were performed. The newly synthesized compounds, as expected, showed a binding mode similar to the one observed for derivatives IIIe and IIIf, with the t-butyl ester inserted in to the lateral subpocket, the indole core occupying the deepest part of the site and the thiophenol ring positioned in the more solvent exposed portion of the pocket. Figure 6 reports compound IIc in the active site.

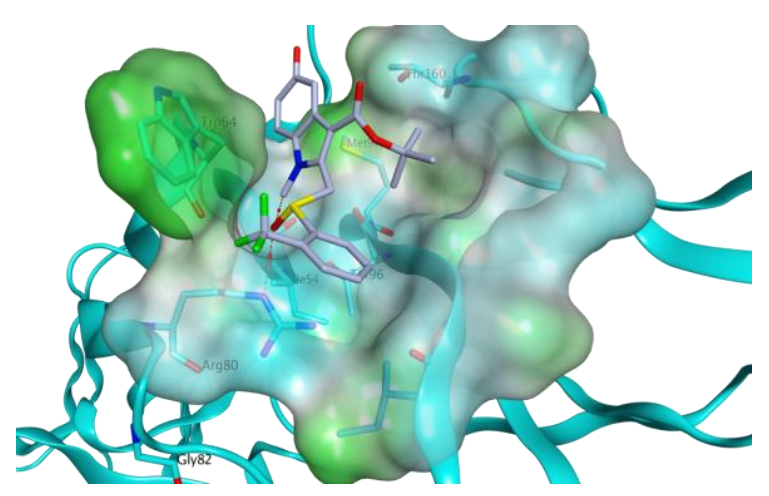

Fig.6 
Based on the CHIKVpp data and the docking results, it could be speculated that the different binding to E2 observed for the new derivative IIc and for compound IIIf (as consequence of the structural modifications) could be responsible for the decrease in the inhibition of CHIKVpp entry into BGM cells, whereas Arbidol occupation of the binding pocket is resulting in a much larger inhibition of CHIKVpp entry.

\section{Conclusion}

Here we highlight the progress towards the discovery of CHIKV inhibitors with an indole core structure. From our structure activity relationship analysis Tert-butyl-5-hydroxy-1-methyl-2-(2trifluoromethysulfynyl)methyl)-indole-3-carboxilate (IIc) emerged as a new inhibitor of CHIKV replication at a post-entry step of the viral life cycle, besides a modest effect on viral entry, suggesting that additional inhibitory mechanisms may be present that contribute to its potent antiviral activity. 


\section{Experimental section}

\section{Chemistry}

All reagents were analytical grade and purchased from Sigma-Aldrich (Milano, Italy). Flash chromatography was performed on Carlo Erba silica gel 60 (230-400 mesh; CarloErba, Milan, Italy). TLC was carried out using plates coated with silica gel 60F $254 \mathrm{~nm}$ purchased from Merck (Darmstadt, Germany). ${ }^{1} \mathrm{H}$ and ${ }^{13} \mathrm{C}$ NMR spectra were registered on a Brucker AC 300. Chemical shifts are reported in ppm. Yields are given for isolated products showing one spot on a TLC plate and no impurities detectable in the NMR spectrum. The abbreviations used are follows: s, singlet; d, doublet; dd double doublet; bs, broad signal. Mass spectral analyses were carried out using an electrospray spectrometer, Finnigan LCQ Deca. The purity (95\% or higher) of all final products that were evaluated for bioactivity was assessed by HPLC. The analytical HPLC analyses were carried out on Beckman Coulter $125 \mathrm{~S}$, equipped with two high pressure binary gradient delivery systems, a System Gold 166 variable-wavelength UV e vis detector and a Rheodyne 7725i injector (Rheodyne, Inc., Cotati, CA, USA) with a 20-mL stainless steel loop. For the analytical tests, compounds were prepared dissolving in methanol $(0.5 \mathrm{mg} / \mathrm{mL})$. Each solution $(20 \mathrm{~mL})$ was injected in a Jupiter Phenomenex RP $18\left(4.5 \_250 \mathrm{~mm}\right)$ analytical column. The mobile phase was a combination mixture of $\mathrm{H}_{2} \mathrm{O}+0.1 \%$ TFA (solvent $\mathrm{A}$ ) and $\mathrm{CH}_{3} \mathrm{CN}+$ $0.1 \%$ TFA (solvent B). The elution was made in gradient from $5 \%$ of $\mathrm{B}$ to $71 \%$ in $35 \mathrm{~min}$, the flow rate was $1.0 \mathrm{~mL} / \mathrm{min}$.

\section{1 tert-butyl 3-iminobutanoate (4)}

A mixture of tert-butyl acetoacetate (3) $(2.0 \mathrm{~g}, 12.389 \mathrm{mmol})$, aqueous ammonium hydroxyde solution $(25 \%$ wlv, $19.642 \mathrm{ml}, 185.835 \mathrm{mmol})$ in methanol $(20.0 \mathrm{ml})$ was stirred for an hour. The mixture was partitioned between water $(20 \mathrm{~mL})$ and ethyl acetate $(3 \times 30 \mathrm{~mL})$. The combined extracts were washed with brine $(15 \mathrm{~mL})$, dried over $\mathrm{Na}_{2} \mathrm{SO}_{4}$ and evaporated under vacuum to 
give the compound 4 as a pale yellow oil. Yield: $80 \%$. Rf: 0.60 (hexane/ethyl acetate 9/1). ${ }^{1} \mathrm{H}$ NMR (300 MHz, $\left.\mathrm{CDCl}_{3}\right): \delta 4.31(\mathrm{~s}, 1 \mathrm{H}), 1.79(\mathrm{~s}, 3 \mathrm{H}), 1.4(\mathrm{~s}, 9 \mathrm{H})$.

\subsection{Tert-butyl 5-hydroxy-2-methyl-1H-indole-3-carboxylate (5)}

Compound $4(1.6 \mathrm{~g}, 9.991 \mathrm{mmol})$ was added drop wise to a solution of a 1,4-benzoquinone $(1.1 \mathrm{~g}$, $9.991 \mathrm{mmol})$ and zinc iodide $(0.632 \mathrm{~g}, 1.982 \mathrm{mmol})$ refluxed in dry DCM $(18 \mathrm{ml})$ for $2 \mathrm{~h}$ and then cooled at $0^{\circ} \mathrm{c}$ for $30^{\prime}$. The reaction mixture was diluted with ethyl acetate and washed with water $(7 \mathrm{~mL})$. The layers were separated and the organic phase dried over $\mathrm{Na}_{2} \mathrm{SO}_{4}$ and concentrated. The product was purified by flash chromatography using hexane/ethyl acetate 8:2. Brown powder. Yield 74\%. Rf: 0.22 (hexane/ethyl acetate 8/2). ${ }^{1} \mathrm{H}$ NMR (300 MHz, $\mathrm{CDCl}_{3}$ ): $\delta$ 7,25 (s, $1 \mathrm{H}), 7,10(\mathrm{~d}, 1 \mathrm{H}), 6,67(\mathrm{~d}, 1 \mathrm{H}), 2,52(\mathrm{~s}, 3 \mathrm{H}), 1,51(\mathrm{~s}, 9 \mathrm{H})$

\subsection{Procedures for synthesis of compound (6)}

\subsubsection{Tert-butyl 5-acetoxy-2-methyl-1H-indole-3-carboxylate}

A mixture of tert-butyl 5-hydroxy-2-methyl-1H-indole-3-carboxylate (5) (1.8g, 7.33mmol), acetic anhydride $(13.83 \mathrm{ml}, 146.67 \mathrm{mmol})$ and pyridine $(1.78 \mathrm{ml}, 21.99 \mathrm{mmol})$ was refluxed for 1h. The cooled reaction mixture was then washed with saturated sodium bicarbonate solution. After extraction with ethyl acetate, the combined organic layer were washed with a solution of citric acid $10 \%$, dried over $\mathrm{Na}_{2} \mathrm{SO}_{4}$ and concentrated. The crude product was used directly without further purification. Yield 93\% Rf: 0.61 (hexane/ethyl acetate 6/4). ${ }^{1} \mathrm{H}$ NMR (300 MHz, $\left.\mathrm{CDCl}_{3}\right): \delta 7.78(\mathrm{~s}, 1 \mathrm{H}), 7.22(\mathrm{~d}, 1 \mathrm{H}), 6.98(\mathrm{~d}, 1 \mathrm{H}), 2.72(\mathrm{~s}, 3 \mathrm{H}), 2,34(\mathrm{~s}, 3 \mathrm{H}), 1.65(\mathrm{~s}, 9 \mathrm{H})$.

\subsubsection{Tert-butyl -5- acetoxy-1,2-dimethyl-indole-3-carboxylate (6)}

A mixture of tert-butyl 5-acetoxy-2-methyl-1H-indole-3-carboxylate $(1.9 \mathrm{~g}, 6.789 \mathrm{mmol})$, anhydrous DMF (22ml) and NaH 95\% (0.24g, 10.183mmol) was stirred at RT until clear, then iodomethane $(1.3 \mathrm{ml}, 20.367 \mathrm{mmol})$ were added. After $1 \mathrm{~h}$ the reaction was quenched with $\mathrm{H}_{2} \mathrm{O}$ 
and extracted with DCM. The organic phase was washed with a solution of citric acid $10 \%$ for two times, then dried over $\mathrm{Na}_{2} \mathrm{SO}_{4}$, filtrated and evaporated. The purification by silica column was not necessary. Yield 81\%; Rf: 0.50 (hexane/ethyl acetate 7/3). ${ }^{1} \mathrm{H}$ NMR $\left(300 \mathrm{MHz}, \mathrm{CDCl}_{3}\right)$ : $\delta 7.81(\mathrm{~s}, 1 \mathrm{H}), 7.10(\mathrm{~d}, 1 \mathrm{H}), 6.89(\mathrm{~d}, 1 \mathrm{H}), 3.43(\mathrm{~s}, 3 \mathrm{H}), 2.61(\mathrm{~s}, 3 \mathrm{H}), 1.67(\mathrm{~s}, 9 \mathrm{H})$.

\subsection{General procedures for the compounds $7 \mathrm{a}$ and $7 \mathrm{~b}$}

A solution of $6(1.7 \mathrm{~g}, 5.499 \mathrm{mmol})$ in $\mathrm{CCl}_{4}(30 \mathrm{ml})$ was brought to reflux: then $\mathrm{N}$ bromosuccinimide $(0.979 \mathrm{~g}, 5.499 \mathrm{mmol})$ and dibenzoyl peroxide $(0.093 \mathrm{~g}, 0.385 \mathrm{mmol})$ were added. After $2 \mathrm{~h}$ the solution was cooled to RT and water was added.

The reaction mixture was washed with brine, dried over $\mathrm{Na}_{2} \mathrm{SO}_{4}$ and concentrated under reduced pressure. The product was purified by flash chromatography using hexane/ethyl acetate $8 / 2$ as eluent. From this purification we recovered tert-butyl-5-acetoxy-2-(bromomethyl)-1-methylindole-3-carboxilate (7a) and tert-butyl-5-acetoxy-6-bromo-2-(bromomethyl)-1-methyl -indole3-carboxilate (7b) in yield 60 and 30\% respectively.

\subsubsection{Tert-butyl 5-acetoxy-2-(bromomethyl)-1-methyl-indole-3-carboxilate (7a)}

Yield 60\% Rf: 0.55 (hexane/ethyl acetate 7/3). ${ }^{1} \mathrm{H}$ NMR $\left(300 \mathrm{MHz}, \mathrm{CDCl}_{3}\right): \delta 7.87(\mathrm{~s}, 1 \mathrm{H}) ; 7,26$ $(\mathrm{d}, 1 \mathrm{H}) ; 7,02(\mathrm{~d}, 1 \mathrm{H}) ; 5,05(\mathrm{~s}, 2 \mathrm{H}) ; 3,71(\mathrm{~s}, 3 \mathrm{H}) ; 2,34(\mathrm{~s}, 3 \mathrm{H}) ; 1,68(\mathrm{~s}, 9 \mathrm{H})$.

\subsubsection{Tert-butyl-6-bromo-5-acetoxy-2-(bromomethyl)-1-methyl-indole-3-carboxilate (7b)}

Yield 30\%. Rf: 0.66 (hexane/ethyl acetate 7/3). ${ }^{1} \mathrm{H}$ NMR (300MHz, $\left.\mathrm{CDCl}_{3}\right): \delta 7.93(\mathrm{~s}, 1 \mathrm{H}) ; 7,60$ $(\mathrm{s}, 1 \mathrm{H}) ; 5,10(\mathrm{~s}, 2 \mathrm{H}) ; 3,78(\mathrm{~s}, 3 \mathrm{H}) ; 2,40(\mathrm{~s}, 3 \mathrm{H}) ; 1,67(\mathrm{~s}, 9 \mathrm{H})$.

\subsection{General procedures for the compounds I a-g}

To a stirred solution of thiophenol $(1 \mathrm{mmol})$ and $\mathrm{KOH}(0.168 \mathrm{~g}, 3 \mathrm{mmol})$ in water $(3 \mathrm{~mL})$, after 15 min 1 eq. of compound $7 \mathrm{a}$ or $7 \mathrm{~b}$ was added. The reaction mixture was stirred at RT for $3 \mathrm{~h}$. After neutralization with acetic acid. The solution was washed with water and extracted with 
DCM for two times. The organic layer were dried and evaporated. The product was purified by flash chromatography using Hexane/ethyl acetate 7/3 as eluent.

4.5.1 Tert-butyl-5-hydroxy-1-methyl-2-(4-trifluoromethylphenylthio)methyl)-indole-3carboxilate Ia

Yield 42\% Rf: 0.30 (hexane/ethyl acetate 7/3). ${ }^{1} \mathrm{H}$ NMR $\left(300 \mathrm{MHz}, \mathrm{CDCl}_{3}\right): \delta 7,55(\mathrm{~d}, 1 \mathrm{H}) ; \delta$ $7,48(\mathrm{~m}, 4 \mathrm{H}) ; \delta 7,21(\mathrm{~d}, 1 \mathrm{H}) ; \delta 6,88(\mathrm{dd}, 1 \mathrm{H}) ; \delta 4,83(2 \mathrm{H}) ; \delta 3,76(\mathrm{~s}, 3 \mathrm{H}) ; \delta 1,60(\mathrm{~s}, 9 \mathrm{H}) .{ }^{13} \mathrm{C} \mathrm{NMR}$ $\left(300 \mathrm{MHz}, \mathrm{CDCl}_{3}\right): \delta=28.7,30.1,80.3,106.7,110.2,112.5,125.6,130.3,132.25,141.4,151.3$ 164.8. $\operatorname{ESI}(\mathrm{m} / \mathrm{z}): 438.16\left[\mathrm{M}^{+}+1\right]$.

4.5.2

Tert-butyl-5-hydroxy-1-methyl-2-(2,6-dichlorophenylthio)methyl)-indole-3carboxilate Ib

Yield 64\%. Rf: 0.55 (hexane/ethyl acetate 7/3). ${ }^{1} \mathrm{H}$ NMR (300MHz, $\left.\mathrm{CDCl}_{3}\right): \delta 7.50(\mathrm{~d}, 1 \mathrm{H}) ; 7,33$ $(\mathrm{d}, 2 \mathrm{H}) ; 7,18(\mathrm{~d}, 1 \mathrm{H}) ; 7,16(\mathrm{~d}, 1 \mathrm{H}) ; 6,86(\mathrm{dd}, 1 \mathrm{H}) ; 4,72(\mathrm{~s}, 2 \mathrm{H}) ; 3,75(\mathrm{~s}, 3 \mathrm{H}) ; 1,60(\mathrm{~s}, 9 \mathrm{H}) .{ }^{13} \mathrm{C}$ NMR $\left(300 \mathrm{MHz}, \mathrm{CDCl}_{3}\right): \delta=28.6,30.1,81.3,109.5,115.0,126.2,131.3,133.1,154.3,165.7$. $\operatorname{ESI}(\mathrm{m} / \mathrm{z}): 460.16\left[\mathrm{M}^{+}+23\right]$

4.5.3 Tert-butyl-5-hydroxy-1-methyl-2-(2-trifluoromethylphenylthio)methyl)-indole-3carboxilate Ic

Yield 51\%. Rf: 0.51 (hexane/ethyl acetate 7/3). ${ }^{1} \mathrm{H}$ NMR $\left(300 \mathrm{MHz}, \mathrm{CDCl}_{3}\right): \delta 7,66(\mathrm{~d}, 1 \mathrm{H}) ; 7,58$ $(\mathrm{s}, 1 \mathrm{H}) ; 7,52(\mathrm{~d}, 1 \mathrm{H}) ; 7,43-7,31(\mathrm{~m}, 2 \mathrm{H}) ; 7,18(\mathrm{~d}, 1 \mathrm{H}) ; 6,87(\mathrm{~d}, 1 \mathrm{H}) ; 4,80(\mathrm{~s}, 2 \mathrm{H}) ; 3,68(\mathrm{~s}, 3 \mathrm{H}) ; 1,60$ $(\mathrm{s}, 9 \mathrm{H}) .{ }^{13} \mathrm{C} \mathrm{NMR}\left(300 \mathrm{MHz}, \mathrm{CDCl}_{3}\right): \delta=28.5,29.6,80.2,106.7,110.1,112.5,126.7,127.2$, $131.9,132.3,134.6,141.4,151.3,164.8 . \mathrm{ESI}(\mathrm{m} / \mathrm{z}): 438.14\left[\mathrm{M}^{+}+1\right]$. 
4.5.4 Tert-butyl-6-bromo-5-hydroxy-1-methyl-2-(2-trifluoromethylphenylthio)methyl)indole-3-carboxilate Id

Yield 50\%. Rf: 0.79 (hexane/ethyl acetate 7/3). ${ }^{1} \mathrm{H}$ NMR $\left(300 \mathrm{MHz}, \mathrm{CDCl}_{3}\right) \delta=7,89(\mathrm{~s}, 1 \mathrm{H}) ; 7,67$ $(\mathrm{d}, 1 \mathrm{H}) ; 7,56(\mathrm{~s}, 1 \mathrm{H}) ; 7,50(\mathrm{~d}, 1 \mathrm{H}) ; 7,41-7,35(\mathrm{~m}, 2 \mathrm{H}) ; 4,79(\mathrm{~s}, 2 \mathrm{H}) ; 3,69(\mathrm{~s}, 3 \mathrm{H}) ; 1,58(\mathrm{~s}, 9 \mathrm{H}) .{ }^{13} \mathrm{C}$ NMR (300 MHz, $\left.\mathrm{CDCl}_{3}\right): \delta=20.9,28.4,30.3,80.6,110.9,113.6,116.1,126.8,135.2,142.8$, 164.0, 169.5. $\mathrm{ESI}(\mathrm{m} / \mathrm{z}): 538.06\left[\mathrm{M}^{+}+23\right]$.

4.5.5 Tert-butyl-5-hydroxy-1-methyl-2-(4-fluorophenylthio)methyl)-indole-3-carboxilate Ie Yield 51\%. Rf: 0.38 (hexane/ethyl acetate 7/3). $\quad{ }^{1} \mathrm{H}$ NMR (300MHz, $\left.\mathrm{CDCl}_{3}\right): \delta 7,45(\mathrm{~d}, 1 \mathrm{H})$; 7,32-7,24 (m,3H), 6,99-6,93 (m,2H); 6,86 (dd, 1H); 4,66 (s,2H); 3,67 (s,3H); 1,60 (s,9H). ${ }^{13} \mathrm{C}$ $\operatorname{NMR}\left(300 \mathrm{MHz}, \mathrm{CDCl}_{3}\right): \delta=28.5,30.1,80.2,106.7,110.0,112.2,115.7,126.5,127.2,132.2$ 135.6, 142.6, 151.2, 164.4. $\operatorname{ESI}(\mathrm{m} / \mathrm{z}): 410.2\left[\mathrm{M}^{+}+23\right]$.

\subsubsection{Tert-butyl-5-hydroxy-1-methyl-2-(4-chlorophenylthio)methyl)-indole-3-carboxilate} If Yield 59\%. Rf: 0.41 (hexane/ethyl acetate 7/3). ${ }^{1} \mathrm{H}$ NMR (300MHz, $\left.\mathrm{CDCl}_{3}\right): \delta 7,55(\mathrm{~d}, 1 \mathrm{H})$; 7,27-7,18 (m,5H); 6,82 (dd,1H); 4,70 (s,2H); 3,70 (s,3H); 1,58 (s,9H). ${ }^{13} \mathrm{C}$ NMR (300 MHz, $\left.\mathrm{CDCl}_{3}\right): \delta=29.4,30.0,80.2,106.7,110.0,112.3,127.1,128.9,133.8,142.2,151.3,164.7$ $\operatorname{ESI}(\mathrm{m} / \mathrm{z}): 404.1\left[\mathrm{M}^{+}+1\right]$.

4.5.7 Tert-butyl-6-bromo-5-hydroxy-1-methyl-2-(2,6-dichlorophenylthio)methyl)-indole-3carboxilate Ig

Yield 39\%. Rf: 0.62 (hexane/ethyl acetate 7/3). ${ }^{1} \mathrm{H} \mathrm{NMR}\left(300 \mathrm{MHz}, \mathrm{CDCl}_{3}\right) \delta$ 7,67 (s,1H); 7,43 $(\mathrm{s}, 1 \mathrm{H}) ; 7,31(\mathrm{~d}, 1 \mathrm{H}) ; 7,30(\mathrm{~s}, 1 \mathrm{H}) ; 7,16(\mathrm{dd}, 1 \mathrm{H}) ; 5,30(\mathrm{~s}, 1 \mathrm{H}) ; 4,70(\mathrm{~s}, 2 \mathrm{H}) ; 3,72(\mathrm{~s}, 3 \mathrm{H}) ; 1,52$ (s,9H). ${ }^{13} \mathrm{C}$ NMR (300 MHz, $\left.\mathrm{CDCl}_{3}\right): \delta=28.6,30.1,80.1,107.4,112.2,128.4,130.5,142.4$, 142.9, 147.3, 164.0. $\operatorname{ESI}(\mathrm{m} / \mathrm{z}): 517.97\left[\mathrm{M}^{+}+1\right]$ 


\subsection{General procedure for the compounds II a-f.}

To a solution containing 1 equiv of $\mathbf{I}$ a-f in $\mathrm{CH}_{2} \mathrm{Cl}_{2}(1.5 \mathrm{~mL}), 1.3$ equiv of $\mathrm{MCPBA} 77 \%$ were added and the reaction mixture was stirred for 5 min. Then $\mathrm{Na}_{2} \mathrm{SO}_{3}$ was added and the reaction mixture was extracted with $\mathrm{CHCl}_{3}$. The organic layer was dried over sodium sulfate and evaporated under vacuum to yield a red oil. The crude product was precipitated by addition of a mixture hexane/ethyl acetate.

4.6.1

Tert-butyl-5-hydroxy-1-methyl-2-(4-trifluoromethysulfynyl)methyl)-indole-3carboxilate IIa

Yield 55\%. Rf: 0.60 (hexane/ethyl acetate 7/3) ${ }^{1} \mathrm{H}$ NMR (300MHz, $\left.\mathrm{CDCl}_{3}\right) \delta 7,76(\mathrm{~m}, 4 \mathrm{H}) ; 7,50$ $(\mathrm{s}, 1 \mathrm{H}) ; 7,11(\mathrm{~d}, 1 \mathrm{H}) ; 6,85(\mathrm{dd}, 1 \mathrm{H}) ; 5,02(\mathrm{~d}, 1 \mathrm{H}) ; 4,65(\mathrm{~d}, 1 \mathrm{H}) ; 3,70(\mathrm{~s}, 3 \mathrm{H}) ; 1,60(\mathrm{~s}, 9 \mathrm{H}) .{ }^{13} \mathrm{C}$ NMR $\left(300 \mathrm{MHz}, \mathrm{CDCl}_{3}\right): \delta=28.5,30.6,54.7,80.6,106.5,110.6,113.1,124.8,125.9,126.7,132.5$ 136.1, 151.6, 164.8. $\operatorname{ESI}(\mathrm{m} / \mathrm{z}): 476.13\left[\mathrm{M}^{+}+23\right]$.

4.6.2 Tert-Butyl-5-hydroxy-1-methyl-2-((2,6-dichlorophenylsulfynyl)methyl)-indol-3carboxylate IIb

Yield 40\%. Rf: 0.83 (hexane/ethyl acetate 8/2) ${ }^{1} \mathrm{H}$ NMR (300MHz, $\left.\mathrm{CDCl}_{3}\right) \delta$ 7,50 (d,1H); 7,35 $(\mathrm{s}, 3 \mathrm{H}) ; 7,22(\mathrm{~d}, 1 \mathrm{H}) ; 6,85(\mathrm{dd}, 1 \mathrm{H}) ; 5,57(\mathrm{~d}, 1 \mathrm{H}) ; 5,25(\mathrm{~d}, 1 \mathrm{H}) ; 3,82(\mathrm{~s}, 3 \mathrm{H}) ; 1,61(\mathrm{~s}, 9 \mathrm{H}) .{ }^{13} \mathrm{C}$ NMR $\left(300 \mathrm{MHz}, \mathrm{CDCl}_{3}\right): \delta=28.1,31.6,53.7,80.5,105.8,110.0,113.8,125.0,125.9,126.7,133.5$, 136.1, 154.6, 165.0. $\operatorname{ESI}(\mathrm{m} / \mathrm{z}): 455.05\left[\mathrm{M}^{+}+1\right]$.

\subsubsection{Tert-butyl-5-hydroxy-1-methyl-2-(2-trifluoromethysulfynyl)methyl)-indole-3-} carboxilate IIc

Yield 82\%. Rf: 0.78 (hexane/ethyl acetate 7/3) ${ }^{1} \mathrm{H}$ NMR (300MHz, $\left.\mathrm{CDCl}_{3}\right) \delta$ 7,69 (d,1H); 7,637,53 (m,3H); 7,41 (d,1H); 7,23 (d,1H); 6,85 (dd,1H); 5,20 (d,1H); 4,90 (d,1H); 3,81 (s,3H); 1,49 
$(\mathrm{s}, 9 \mathrm{H}) .{ }^{13} \mathrm{C}$ NMR $\left(300 \mathrm{MHz}, \mathrm{CDCl}_{3}\right): \delta=28.8,31.2,50.7,80.3,106.6,110.5,112.8,126.2$, 131.2, 132.1, 134.8, 151.2, 164.0 ESI(m/z): $476.15\left[\mathrm{M}^{+}+23\right]$.

4.6.4 Tert-butyl-6-bromo-5- hydroxy -1-methyl-2-(2-trifluoromethysulfynyl)methyl)-indole3-carboxilate IId

Yield 60\%. Rf: 0,22 (hexane/ethyl acetate 7/3) ${ }^{1} \mathrm{H}$ NMR (300MHz, $\left.\mathrm{CDCl}_{3}\right): \delta 7,78(\mathrm{~s}, 1 \mathrm{H}) ; 7,70$ $(\mathrm{d}, 1 \mathrm{H}) ; 7,62(\mathrm{~s}, 1 \mathrm{H}) ; 7,52(\mathrm{~m}, 3 \mathrm{H}) ; 5,18(\mathrm{~d}, 1 \mathrm{H}) ; 4,85(\mathrm{~d}, 1 \mathrm{H}) ; 3,8(\mathrm{~s}, 3 \mathrm{H}) ; 1,58(\mathrm{~s}, 9 \mathrm{H}) .{ }^{13} \mathrm{C}$ NMR $\left(300 \mathrm{MHz}, \mathrm{CDCl}_{3}\right): \delta=29.9,37.4,40.4,59.2,89.6,120.4,123.0,125.1,135.0,140.4,144.9$, 152.0, 172.6 ESI(m/z): $556.12\left[\mathrm{M}^{+}+23\right]$.

4.6.5 Tert-butyl-5-hydroxy-1-methyl-2-((4-fluorophenylsulfynyl)methyl)-indole-3carboxilate IIe

Yield 50\% Rf: 0.14 (hexane/ethyl acetate 7/3) ${ }^{1} \mathrm{H}$ NMR $\left(300 \mathrm{MHz}, \mathrm{CDCl}_{3}\right): \delta 7,81(\mathrm{~d}, 1 \mathrm{H}) ; 7,57-$ 7,52 (m,2H); $7.29(\mathrm{~d}, 1 \mathrm{H}) ;$ 7,17-7,12 (m,2H); 7,06 (dd,1H); 4,85 (d,1H); 4,72 (d,1H); 3,63 (s,3H); 1,62 (s,9H). ${ }^{13} \mathrm{C}$ NMR $\left(300 \mathrm{MHz}, \mathrm{CDCl}_{3}\right): \delta=21.2,28.5,30.6,54.4,80.7,110.3,114.3,116.4$, 117.6, 126.5, 135.0, 136.9, 138.5, 146.1, 162.8, 166.2, 170.1. $\mathrm{ESI}(\mathrm{m} / \mathrm{z}): 426.17\left[\mathrm{M}^{+}+23\right]$.

4.6.6 Tert-butyl-5-hydroxy-1-methyl-2-((4-chlorophenylsulfynyl)methyl)-indole-3carboxilate IIf

Yield 97\% Rf: 0.13 (hexane/ethyl acetate 7/3) . ${ }^{1} \mathrm{H}$ NMR (300MHz, CDCl3): $\delta$ 7,44 (m,4H); 7,30 (s, 1H); 7,03 (d, 1H); 6,81 (d, 1H); $4.80(\mathrm{dd}, 2 \mathrm{H}) ; 3,61(\mathrm{~s}, 3 \mathrm{H}) ; 1,63(\mathrm{~s}, 9 \mathrm{H}) .{ }^{13} \mathrm{C}$ NMR (300 MHz, $\left.\mathrm{CDCl}_{3}\right): \delta=28.6,30.5,54.8,80.5,106.5,110.5,113.1,125.8,129.4,132.4,135.9,137.6,141.4$, 151.9, 164.8. $\mathrm{ESI}(\mathrm{m} / \mathrm{z}): 421.08\left[\mathrm{M}^{+}+1\right]$.

\subsection{General procedures for the compounds IV a-d}

A solution of IIb-d (1mmol), N,N, $\mathrm{N}^{\prime}, \mathrm{N}^{\prime}-$ Tetramethylethylenediamine $(2.04 \mathrm{~mL}, 15 \mathrm{mmol})$ and acetic acid $(0.184 \mathrm{~mL})$ was refluxed for $2 \mathrm{~h}$. Then the solvent was evaporated under vacuum and water was added. The resultant mixture was adjusted to $\mathrm{pH} 10$ with sodium hydroxide and 
extracted with methylene chloride. The resulting organic layer was dried over $\mathrm{Na}_{2} \mathrm{SO}_{4}$, filtered and evaporated under vacuum. The product precipitates in diethyl ether.

4.7.1. Tert-butyl 2-((2,6-dichlorophenylthio)methyl)-6-bromo-4-((dimethylamino)methyl)5-hydroxy-1-methyl-1H-indole-3-carboxylate IVa

Yield 59\%. Rf: 0.62 (hexane/ethyl acetate 8/2+0.1eq di TEA) ${ }^{1} \mathrm{H}$ NMR $\left(300 \mathrm{MHz}, \mathrm{CDCl}_{3}\right): \delta$ 7,42 (d,1H); 7,40 (s,1H); 7,23 (dd,1H); $\delta 4,49(\mathrm{~s}, 2 \mathrm{H}) ; 4,16(\mathrm{~s}, 2 \mathrm{H}) ; 3,62(\mathrm{~s}, 3 \mathrm{H}) ; 2,37(\mathrm{~s}, 6 \mathrm{H}) ; 1,62$ (s,9H). ${ }^{13} \mathrm{C}$ NMR (300 MHz, $\left.\mathrm{CDCl}_{3}\right): \delta=27.3,29.0,29.4,42.2,57.6,81.2,113.9,128.6,131.3$, 141.6, 151.8, 165.7 ESI(m/z): $575.08\left[\mathrm{M}^{+}+1\right]$.

4.7.2 Tert-butyl-2-((2,6-dichlorophenylsulfinyl)methyl)-4-((dimethylamino)methyl)-5hydroxy-1-methyl-1H-indole-3-carboxylateilate IVb

Yield 86\%. Rf: 0.67 (hexane/ethyl acetate 8/2+0.1eq di TEA) ${ }^{1} \mathrm{H}$ NMR (300MHz, MeOD): $\delta$ 7,46 (d,1h); 7,31-7,23 (m,3H); 6,79 (dd,1H); 4,68 (s,2H); 3,67 (s,3H); 3,26 (s,6H); 1,60 (s,9H).

${ }^{13} \mathrm{C}$ NMR (300 MHz, MeOD): $\delta=27.4,29.0,29.9,42.2,57.2,81.0,108.3,114.0,128.6,131.0$, 141.7, 142.5, 155.6, 165.9. ESI (m/z): $511.2\left[\mathrm{M}^{+}+1\right]$.

4.7.3 Tert-butyl-2-((2-(trifluoromethyl)phenylsulfinyl)methyl)-4-((dimethylamino)methyl)5-hydroxy-1-methyl-1H-indole-3-carboxylate IVc

White solid. Yield 70\%. Rf: 0.43 (hexane/ethyl acetate 8/2+0.1eq di TEA)

${ }^{1} \mathrm{H}$ NMR (300MHz, $\left.\mathrm{CDCl}_{3}\right): \delta \quad 8,05(\mathrm{~d}, 1 \mathrm{H}) ; 7,77-7,63(\mathrm{~m}, 3 \mathrm{H}) ; 7,15(\mathrm{~d}, 1 \mathrm{H}) ; 6,90(\mathrm{~d}, 1 \mathrm{H}) ; 4,15$ $(\mathrm{d}, 2 \mathrm{H}) ; 3,56(\mathrm{~s}, 3 \mathrm{H}) ; 2,38(\mathrm{~s}, 6 \mathrm{H}) ; 1,63(\mathrm{~s}, 9 \mathrm{H}) .{ }^{13} \mathrm{C} \mathrm{NMR}\left(300 \mathrm{MHz}, \mathrm{CDCl}_{3}\right): \delta=27.4,29.3,43.0$, $59.1,81.2,110.0,114.2,125.8,126.3,132.0,133.2,142.4,154.0,165.9 . \operatorname{ESI}(\mathrm{m} / \mathrm{z}): 533.2\left[\mathrm{M}^{+}+\right.$ 23]. 
((dimethylamino)methyl)-5-hydroxy-1-methyl-1H-indole-3-carboxylate IVd

Yield 70\% Rf: 0.38 (hexane/ethyl acetate 8/2+ 0.1eq di TEA) ${ }^{1} \mathrm{H}$ NMR $\left(300 \mathrm{MHz}, \mathrm{CDCl}_{3}\right): \delta$ 7,90-7,85 (m,2H); 7,83-7,78 (m,2H); 7,57 (s,1H); 4,34 (s,2H); 3,40 (s,3H); $2,51(\mathrm{~s}, 6 \mathrm{H}) ; 1,68$

(s,9H). $\left.{ }^{13} \mathrm{C} \mathrm{NMR} \mathrm{(300} \mathrm{MHz,} \mathrm{CDCl}_{3}\right): \delta=27.4,29.4,42.4,59.1,81.4,113.5,115.3,125.8,126.3$, 132.2, 133.2, 142.2, 154.0, 165.5 $\mathrm{ESI}(\mathrm{m} / \mathrm{z}): 590.0\left[\mathrm{M}^{+}+1\right]$.

\section{Molecular Modeling}

All molecular modeling studies were performed on a MacPro dual $2.66 \mathrm{GHz}$ Xeon running Ubuntu 14.04. The mature E3-E2-E1 glycoprotein complex was downloaded from the PDB data bank (http://www.rcsb.org/; PDB code 3N42). Hydrogen atoms were added to the protein, using the Protonate 3D routine of the Molecular Operating Environment (MOE2015.10). [13] Ligand structures were built with MOE and minimized using the MMFF94x force field until a RMSD gradient of $0.05 \mathrm{kcal} \mathrm{mol}^{-1}$ was reached. The Maestro LigPrep tool [14] was used to prepare the ligands using the default settings, whereas the protein was prepared using the preparation wizard tool. [15] The docking simulations were performed using Maestro Glide XP using the default parameters. [16]

\section{Biological assays}

\subsection{CPE reduction assay}

Vero cells were seeded in 96-well tissue culture plates (BD Falcon 96-Well Cell Culture Plate) at a density of $2.5 \times 10^{4}$ cells/well and were allowed to adhere overnight. Next, a compound dilution series was prepared in the medium on top of the cells after which the cultures were infected with 0.01 MOI of CHIKV 899. Each assay was performed in multiplicate in the same test and assays were repeated independently. On day 5 post-infection (p.i.), the cell viability was quantified 
using the MTS/PMS method as described by the manufacturer (Promega, The Netherlands). The $50 \%$ effective concentration $\left(\mathrm{EC}_{50}\right)$, which is defined as the compound concentration that is required to inhibit virus-induced cytopathogenic effect (CPE) by 50\%, was determined using logarithmic interpolation. The overall anti-metabolic effect of the compounds, which is representative for a combined cytostatic, cytotoxic and anti-metabolic effect, was evaluated in uninfected cells, also using the MTS/PMS method. The 50\% cytostatic/cytotoxic concentration ( $\mathrm{CC}_{50}$; i.e., the concentration of compound that reduces the overall metabolic activity of the cells by $50 \%$ ) was calculated using logarithmic interpolation. All assay wells were checked microscopically for minor signs of virus-induced CPE or alterations of the cell or monolayer morphology.

\subsection{Virus yield assay}

Vero A cells were seeded in 96-well tissue culture plates at a density of $5 \times 10^{4}$ cells/well. After $24 \mathrm{~h}$ of incubation, cells were treated with a serial dilution of the compound followed by infection with CHIKV 899 (MOI 0.001). After 2h, cells were washed twice with assay medium to remove non-adsorbed virus. The cells were then treated again with the same serial dilutions of compound and incubated for $48 \mathrm{~h}$. At the end of the incubation period, culture supernatants were collected for viral RNA isolation using Macherey Nagel NucleoSpin 96 virus kit and viral RNA was quantified by real-time qRT-PCR, while the amount of infectious virus particles was determined by end-point titration assay as described before. [12]

\subsection{CHIKV pseudoparticle entry assay}

CHIKV pseudoparticles (CHIKVpp) were prepared as previously described. [17] BGM cells were seeded in white 96-well tissue culture plates (ViewPlate-96, PerkinElmer) at a density of $2.5 \times 10^{4}$ cells/well and left to adhere overnight. The next day, serial dilutions of the compounds were added to the cells followed by infection with the appropriate dilution of CHIKVpp. Arbidol 
was used as reference compound for entry inhibition. After $72 \mathrm{~h}$, the medium was aspirated from all wells and cells were lysed using Glo lysis buffer (Promega). The firefly luciferase activity in the cell lysate was then detected using the Luciferase Assay System kit (Promega).

\subsection{Time of addition assay}

Vero A cells were seeded in 96-well tissue culture plates at a density of $5 \times 10^{4}$ cells/well and left to adhere overnight. The next day, the compounds were added to the cells either $2 \mathrm{~h}$ prior, at, or after 2, 4, 6 and $8 \mathrm{~h}$ of infection with 1 MOI of CHIKV 899. Following 24 of incubation, cells were lysed by adding Cells-to-cDNA ${ }^{\mathrm{TM}}$ lysis buffer (Life Technologies) and the intracellular viral RNA was quantified by qRT-PCR as described before. [13]

\section{Acknowledgments}

This work was supported by the grant PON 03 PE_00060_07 (MIUR) Sviluppo pre-clinico di nuove terapie e di strategie innovative per la produzione di molecole ad azione farmacologica. We would like to acknowledge the support of the Life Science Research Net- work Wales grant no. NRNPGSep14008, an initiative funded through the Welsh Government's Ser Cymru program. L.D. is funded by the Research Foundation of Flanders (FWO). We thank Caroline Collard and Nick Verstraeten for their excellent technical assistance. 


\section{References:}

[1] S. A. Ziegler, L.Lu, A. P. da Rosa, S. Y. Xiao, R. B. Tesh. An animal model for studying the pathogenesis of chikungunya virus infection. Am. J. Trop. Med. Hyg. 79 (2008) 133-139.

[2] V. Brancato, A. Peduto, S. Wharton, S. Martin, V. More, A. Di Mola, A. Massa, B. Perfetto, G. Donnarumma, C. Schiraldi, M. A. Tufano, M. de Rosa, R. Filosa, A. Hay. Design of inhibitors of influenza virus membrane fusion: synthesis, structure-activity relationship and in vitro antiviral activity of a novel indole series. Antiviral Res. 99 (2013) 125-135.

[3] Y. S. Boriskin, I. A. Leneva, E. I. Pecheur, S. J. Polyak. Arbidol: A broad-spectrum antiviral compound that blocks viral fusion. Curr. Med. Chem. 15 (2008) 997-1005.

[4] S. Delogu, B. Pastorino, C. Baronti, A. Nougairède, E. Bonnet, X. de Lamballerie. In vitro antiviral activity of arbidol against Chikungunya virus and characteristics of a selected resistant mutant. Antiviral Res. 90 (2011) 99-107.

[5] A. Di Mola, A. Peduto, A . La Gatta, L. Delang, B. Pastorino, J. Neyts, P. Leyssen, M. de Rosa, R. Filosa. Structure-activity relationship study of arbidol derivatives as inhibitors of chikungunya virus replication. Bioorg Med Chem. 22 (2014) 6014-25

[6] J.E. Voss, M.C. Vaney, S. Duquerroy, C. Vonrhein, C. Girard-Blanc, E. Crublet, A. Thompson, G. Bricogne, FA Rey. Glycoprotein organization of Chikungunya virus particles revealed by X-ray crystallography. Nature. 468 (2010) 709-712

[7] E. Teissier, G. Zandomeneghi, A. Loquet, D. Lavillette, J.P. Lavergne, R. Montserret, F.L. Cosset, A. Böckmann, B.H. Meier, F. Penin, E.I. Pécheur. Mechanism of inhibition of enveloped virus membrane fusion by the antiviral drug arbidol. PLoS ONE. 6 (2011).

[8] A. Peduto, A. Massa, A. Di Mola, P. de Caprariis, P. La Colla, R. Loddo, S. Altamura, G. Maga, R. Filosa. 2,3-Dihydro-1,2-Diphenyl-substituted 4H-Pyridinone derivatives as new anti Flaviviridae inhibitors, Chem Biol Drug Des. 77 (2011) 441-9.

[9] B. Perfetto, R. Filosa, V. De Gregorio, A. Peduto, A. La Gatta, P. de Caprariis, M.A. Tufano, G. Donnarumma. In vitro antiviral and immunomodulatory activity of arbidol and structurally related derivatives in herpes simplex virus type 1-infected human keratinocytes (HaCat), J Med Microbiol. 63 (2014) 1474-83.

[10] R. Cao, H. Chen, W. Peng, Y. Ma, X. Hou, H. Guan, X. Liu, A. Xu. Design, synthesis and in vitro and in vivo antitumor activities of novel beta-carboline derivatives. Eur. J. Med.nChem. 40 (2005) 991-1001.

[11] F. A.Trofimov, N. Tsyshkova, N. S. Bogdanova, I. S. Nikolaeva, S. A. Zotova, Z. M. Sakhaschik, E.N. Padeyskaya, A.N. Fomina, E.H. Svirina, D.M. Zlydnikov, O.K. Kubar, E.G. Shvetsova, S. V. Kutchak, V.V. Peters, E. A. Bryantseva, A. G. Konoplyannikov, P. G. Surinov, V. A. Yadrovskaya, L. S. Satonova, N.A. Karpova, E.P.nSavina, L.A. Savinova, A.N. Grinev, G.N. Pershin. Patent number 5, 1993, 198, 552. 
[12] L. Delang, N. Segura Guerrero, A. Tas, G. Quérat, B. Pastorino, M. Froeyen, K. Dallmeier, D. Jochmans, P. Herdewijn, F. Bello, E.J. Snijder, X. de Lamballerie, B. Martina, J. Neyts, M.J. van Hemert, P. Leyssen. Mutations in the chikungunya virus non-structural proteins cause resistance to favipiravir (T-705), a broad-spectrum antiviral, J Antimicrob Chemother. 10 (2014) 2770-84.

[13] Molecular Operating Environment (MOE 2015.10); Chemical Computing Group, Inc.: Montreal, Quebec, Canada; URL http://www.chemcomp.com 2015.

[14] Schrödinger Release 2015-4: LigPrep, version 3.6, Schrödinger, LLC, New York, NY, 2015.

[15] Schrödinger Release 2015-4: Schrödinger Suite 2015-4 Protein Preparation Wizard; Epik version 3.4, Schrödinger, LLC, New York, NY, 2015; Impact version 6.9, Schrödinger, LLC, New York, NY, 2015; Prime version 4.2, Schrödinger, LLC, New York, NY, 2015.

[16] Schrödinger, LLC, Small-Molecule Drug Discovery Suite: Glide, version 6.9, New York, NY, 2015.

[17] B. Salvador, Y. Zhou, A. Michault, M.O. Muench, G. Simmons Characterization of chikungunya pseudotyped viruses: identification of refractory cell lines and demonstration of cellular tropism differences mediated by mutations in e1 glycoprotein. Virology 1 (2009) 33-41. 
Fig.1 Two potential Arbidol binding sites in proximity of Gly82 (red circle) in the E2 glycoprotein.

Fig.2 Docking of Arbidol in the two potential binding sites. A) Site 1 is a shallow hydrophilic (turquoise surface) pocket for Arbidol binding. B) Site 2 is a more hydrophobic (green surface) and well-defined pocket that could allow Arbidol binding. The E2 protein is shown as turquoise ribbon.

Fig.3 Docking of IIIe (A, carbon atoms in gold) and IIIf (B, carbon atoms in purple). Both compounds show a different binding mode form Arbidol.

Fig.4 The indole derivatives IIc and IIIf act as specific and selective inhibitors of CHIKV replication. A) Dose-response effect of IIc and IIIf on CHIKV-induced CPE in Vero A cells as quantified by MTS/PMS method. B) Dose-response effect of IIc and IIIf on virus yield of CHIKV-899 in Vero A cells as determined by qRT-PCR (RNA) and C) titration for infectious progeny virus particles $\left(\mathrm{TCID}_{50} / \mathrm{ml}\right)$. Data presented are mean values $\pm \mathrm{SD}$ of at least three independent experiments.

Fig.5 The effect of indole derivatives (IIc and IIIf) on the CHIKV replication cycle. A) The dose-response effect of indole derivatives on the entry of CHIKV pseudoparticles (CHIKVpp) in BGM cells. After $72 \mathrm{~h}$ of infection, cells were lysed and the intracellular firefly luciferase signal was quantified. B) Time-of-addition assay. Vero A cells were treated with the selected compound prior to $(-2 \mathrm{~h})$, at the time of $(0 \mathrm{~h})$, or after infection $(2,4$ and $6 \mathrm{~h})$ with MOI=1 of CHIKV strain 899. After $24 \mathrm{~h}$ of infection, the intracellular viral RNA was quantified by qRTPCR. Arbidol and T-705 were included in these assays as reference compounds for early and late stage inhibition, respectively. Data are average \pm SD of at least three independent experiments.

Fig.6 Docking of IIc (carbon atoms in lilac). The compound shows a binding mode similar to the one observed for IIIe and IIIf. 


\section{Scheme 1}

Reagents and conditions: a) $\mathrm{NH}_{4} \mathrm{OH}, \mathrm{CH}_{3} \mathrm{OH}$, rt, 1h; b) 1,4-benzoquinone, $\mathrm{ZnI}_{2}$, dry DCM, reflux, $1 \mathrm{~h}, 0^{\circ} \mathrm{C}, 30^{\prime}$; c) acetic anhydride, pyridine, reflux, 1h d) $\mathrm{CH}_{3} \mathrm{I}, 60 \% \mathrm{NaH}, \mathrm{DMF}, \mathrm{rt}, 1 \mathrm{~h}$; e) N-Bromosuccinimide, dibenzoylperoxide, $\mathrm{CCl}_{4}$, reflux, $3 \mathrm{~h}$; f) $\mathrm{R}_{1} \mathrm{PhSH}, \mathrm{KOH}, \mathrm{CH}_{3} \mathrm{OH}$, rt, 1h; g) MCPBA, dry DCM, rt, 5'; h-i) TMEDA, acetic acid, DCM, reflux, 2 h.

\section{Table 1}

${ }^{a} \mathrm{CC}_{50}: 50 \%$ cytostatic/cytotoxic concentration (concentration at which $50 \%$ adverse effect is observed on the host cell). ${ }^{\mathrm{b}} \mathrm{EC}_{50}$ : $50 \%$ Effective concentration (concentration at which $50 \%$ inhibition of CPE is observed in Vero cells). ${ }^{c}$ SI: Selectivity index (CC50/EC50).

\section{Table 2}

${ }^{a} \mathrm{CC}_{50}: 50 \%$ cytostatic/cytotoxic concentration (concentration at which $50 \%$ adverse effect is observed on the host cell). ${ }^{\mathrm{b}} \mathrm{EC}_{50}$ : $50 \%$ Effective concentration (concentration at which $50 \%$ inhibition of CPE is observed in Vero cells). ${ }^{c}$ SI: Selectivity index (CC50/EC50).

\section{Table 3}

${ }^{a} \mathrm{CC}_{50}: 50 \%$ cytostatic/cytotoxic concentration (concentration at which $50 \%$ adverse effect is observed on the host cell). ${ }^{\mathrm{b}} \mathrm{EC}_{50}: 50 \%$ Effective concentration (concentration at which $50 \%$ inhibition of CPE is observed in Vero cells). ${ }^{c}$ SI: Selectivity index (CC50/EC50).

\section{Table 4}

Antiviral activity of indole derivatives against selected alphaviruses in Vero A cells. SFV = Semliki Forest virus, SINV = Sindbis virus.

\section{Table 5:}

The inhibitory effect of indole derivatives on the entry of CHIKV pseudoparticles (CHIKVpp) in BGM cells. 


\section{Supporting Information}

\section{Discovery of novel multi-target indole-based derivative as potent and selective inhibitor of Chikungunya Virus replication}

Maria Scuotto $^{\# \mathrm{a}}$, Rana Abdelnabi ${ }^{\mathrm{b} \#}$, Selene Collarile ${ }^{\mathrm{a}}$, Chiara Schiraldi ${ }^{\mathrm{a}}$, Leen Delang ${ }^{\mathrm{b}}$, Antonio Massa $^{\mathrm{d}}$, Salvatore Ferla ${ }^{\mathrm{c}}$, Andrea Brancale ${ }^{\mathrm{c}}$, Mario De Rosa ${ }^{\mathrm{a}}$, Pieter Lyessen ${ }^{\mathrm{b}}$, Johan Neyts ${ }^{\mathrm{b}}$, Rosanna Filosa ${ }^{a^{*}}$

a Department of Experimental Medicine, University of Naples, Via Costantinopoli, 16, 80138 Naples, Italy

b Laboratory of Virology and Experimental Chemotherapy, Rega Institute for Medical Research, KU Leuven, Leuven, Belgium

c School of Pharmacy and Pharmaceutical Sciences, Cardiff University, King Edward VII Avenue, Cardiff CF10 3NB, UK

\section{Corresponding author:}

Rosanna Filosa : Department of Experimental Medicine, Second University of Naples, Via Costantinopoli, 16 - 80138 Naples, Italy; Phone:0815667663; e-mail: rosanna.filosa@unina2.it

\# These authors contribute equally

\section{Contents:}

- ${ }^{1} \mathrm{H}$ and ${ }^{13} \mathrm{C}-\mathrm{NMR}$ spectra of Ia $\mathrm{S} 2$

- ${ }^{1} \mathrm{H}$ and ${ }^{13} \mathrm{C}$-NMR spectra of Ib S3

- ${ }^{1} \mathrm{H}$ and ${ }^{13} \mathrm{C}-\mathrm{NMR}$ spectra of Ic S4

- ${ }^{1} \mathrm{H}$ and ${ }^{13} \mathrm{C}-\mathrm{NMR}$ spectra of If S5

- ${ }^{1} \mathrm{H}$ and ${ }^{13} \mathrm{C}$-NMR spectra of Ig S6 
- ${ }^{1} \mathrm{H}$ and ${ }^{13} \mathrm{C}-\mathrm{NMR}$ spectra of IIa S7

- ${ }^{1} \mathrm{H}$ and ${ }^{13} \mathrm{C}-\mathrm{NMR}$ spectra of IIC S8

- ${ }^{1} \mathrm{H}$ and ${ }^{13} \mathrm{C}-\mathrm{NMR}$ spectra of IIe S9

- ${ }^{1} \mathrm{H}$ and ${ }^{13} \mathrm{C}-\mathrm{NMR}$ spectra of IIf S10

- ${ }^{1} \mathrm{H}$-NMR spectra of IVa and IVb S11

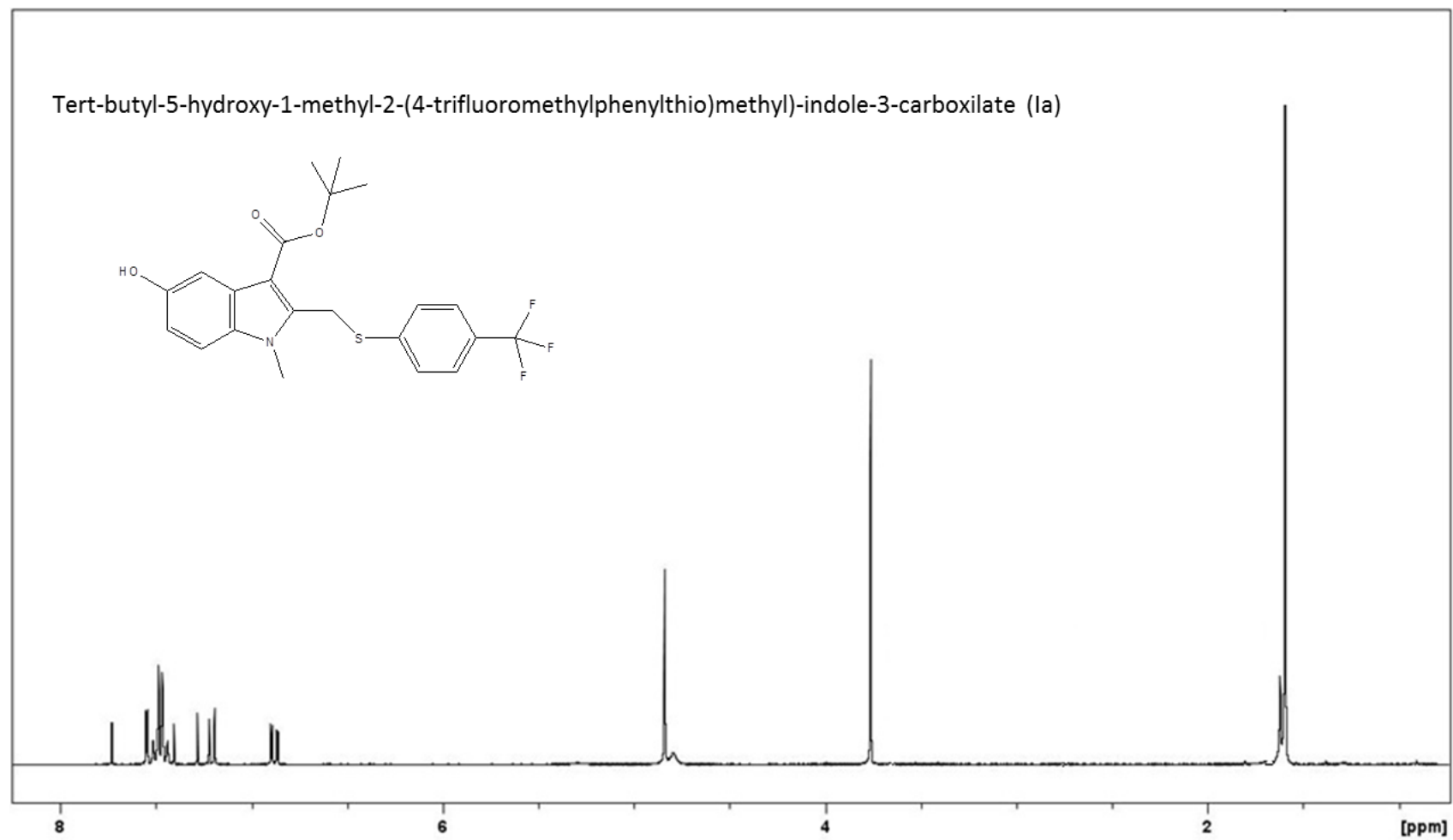


Tert-butyl-5-hydroxy-1-methyl-2-(4-trifluoromethylphenylthio)methyl)-indole-3-carboxilate (la)
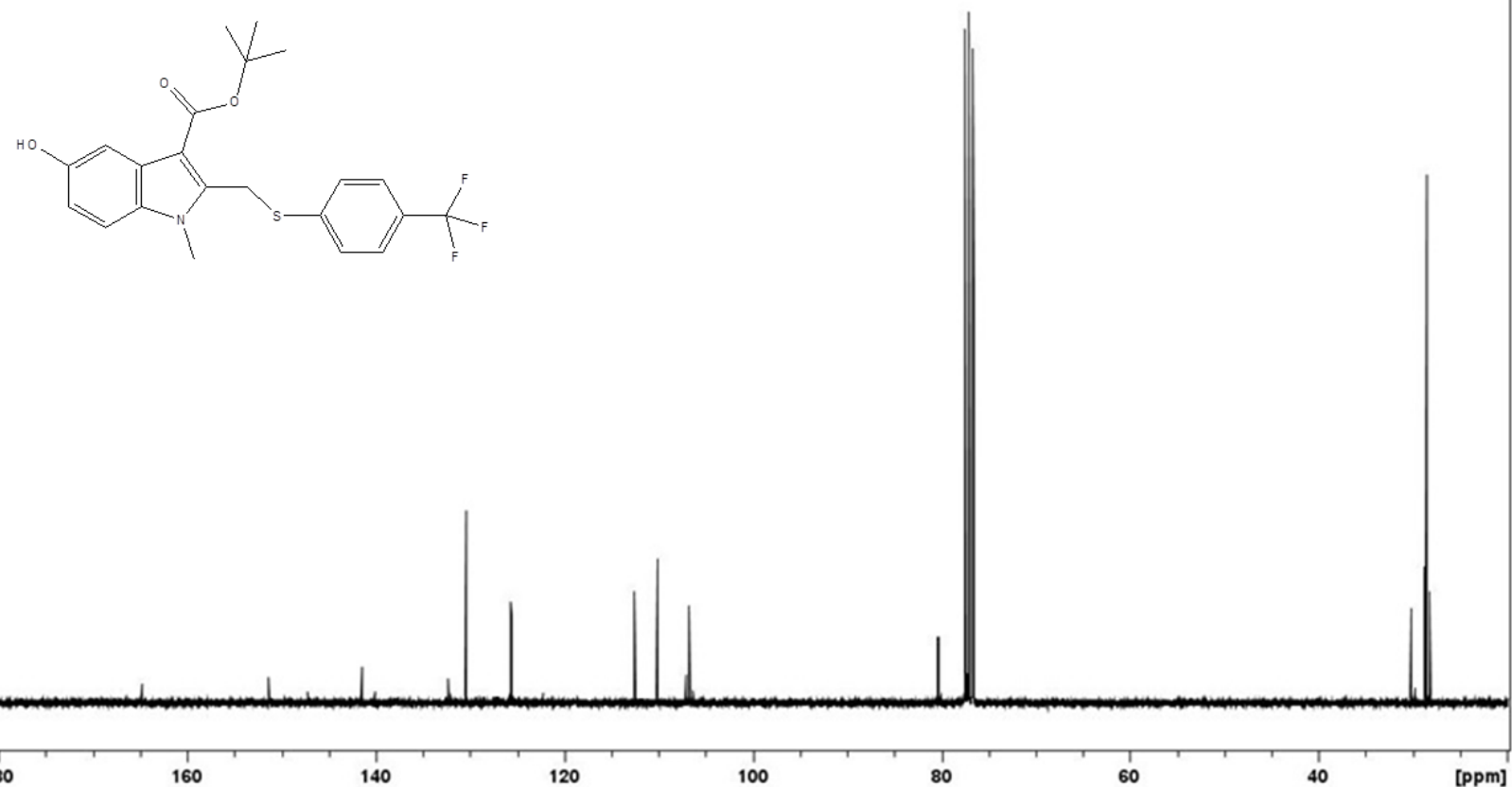

Tert-butyl-5-hydroxy-1-methyl-2-(2,6-dichlorophenylthio)methyl)-indole-3-carboxilate (Ib)
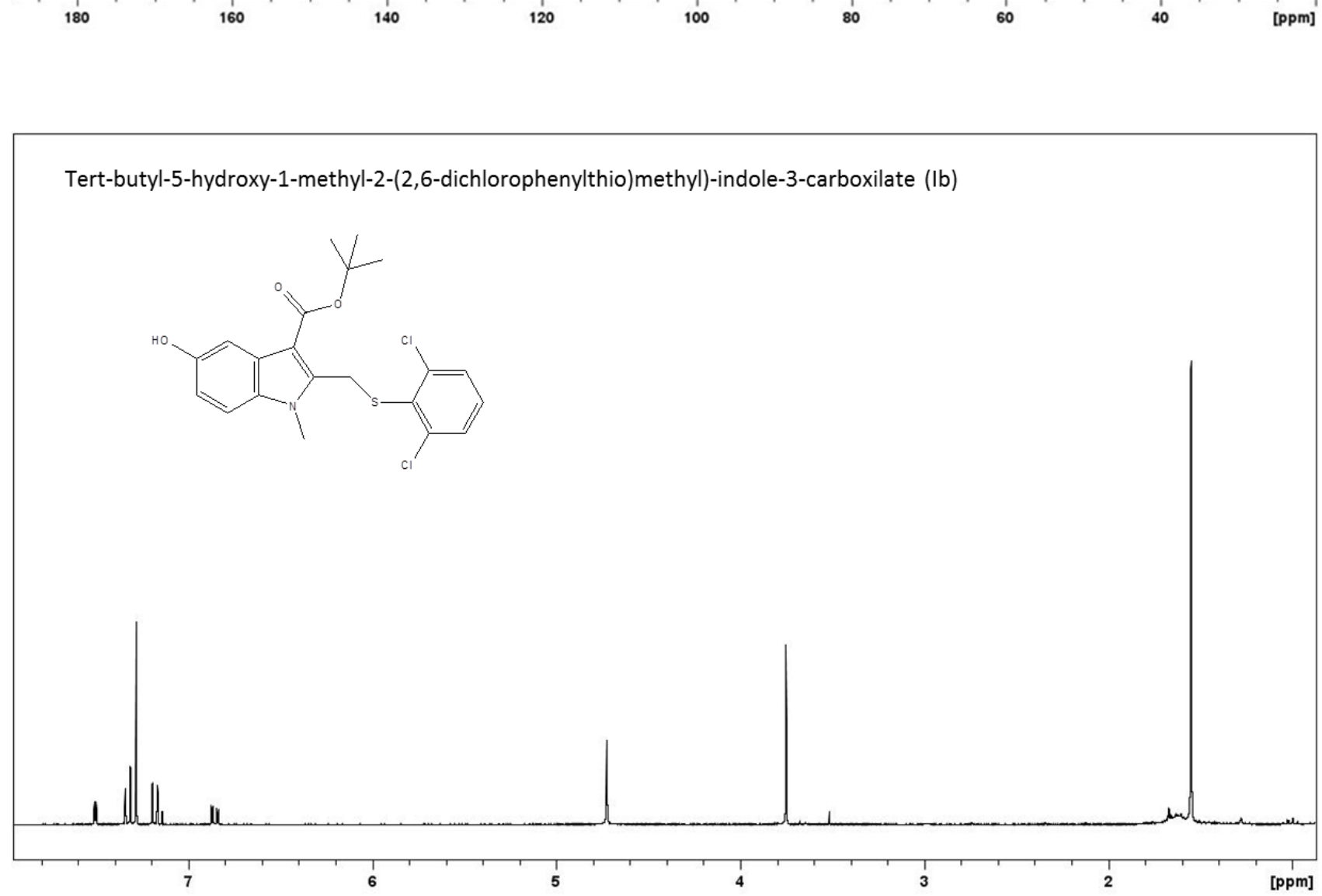

140

120

100 


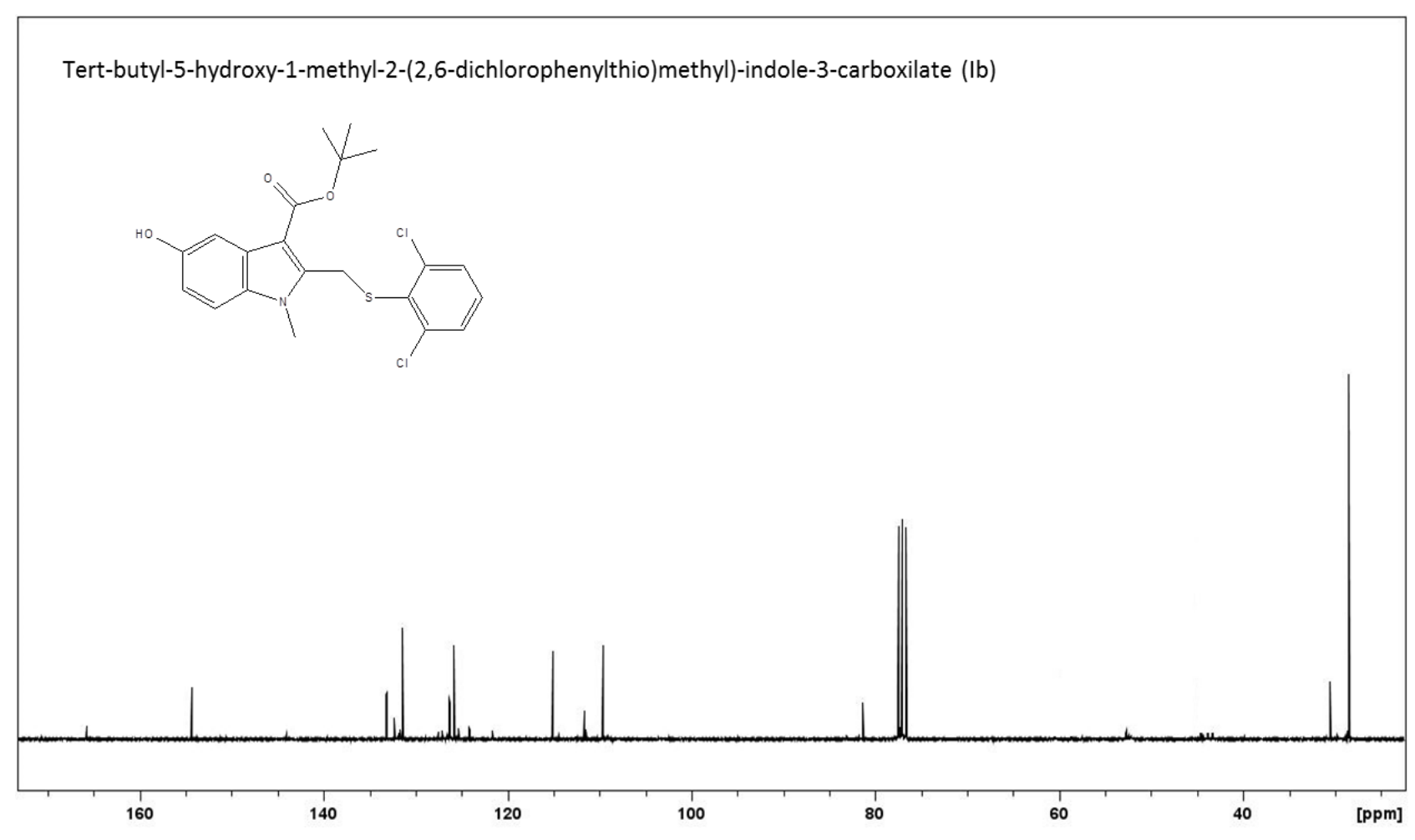




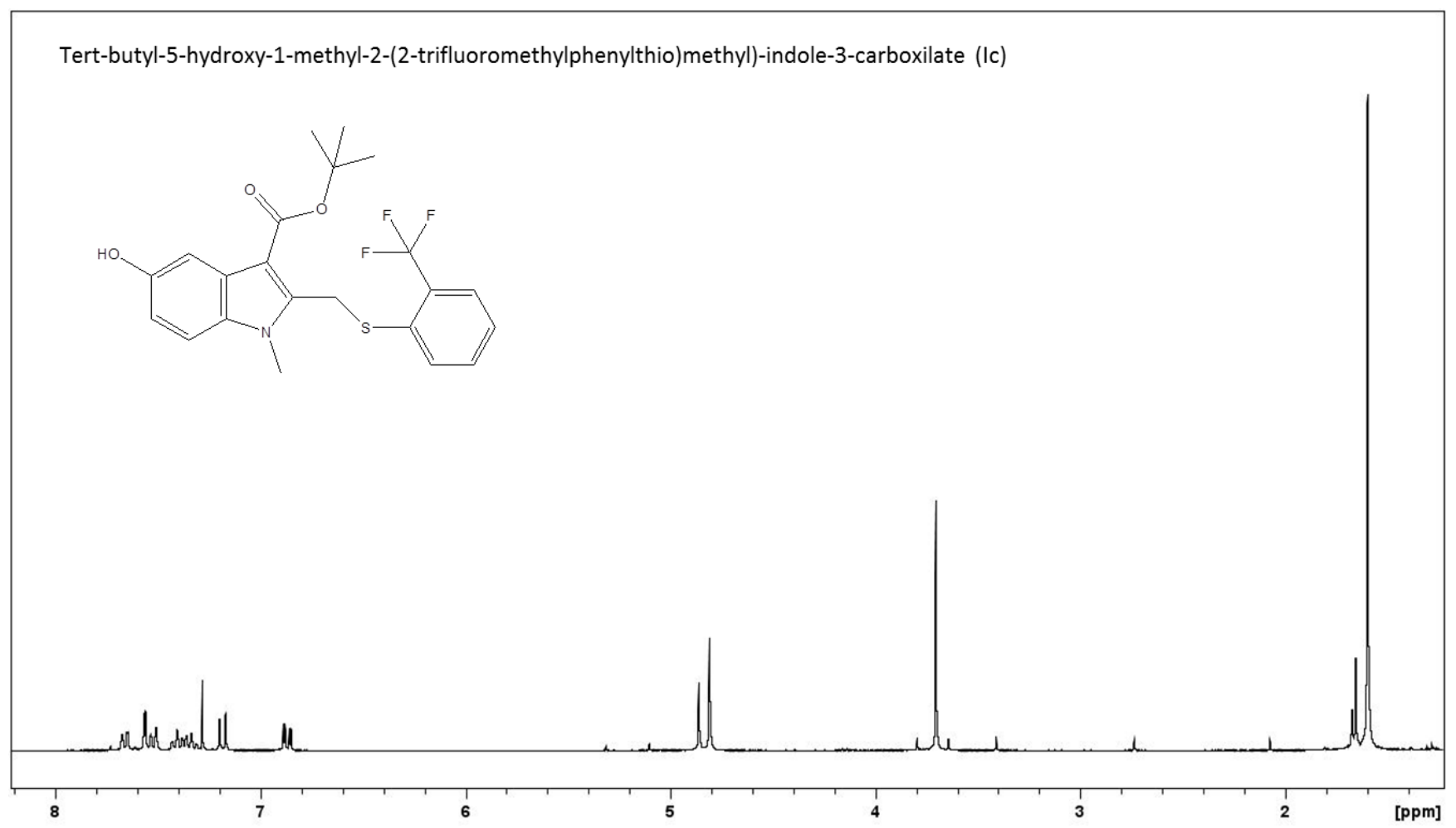

Tert-butyl-5-hydroxy-1-methyl-2-(2-trifluoromethylphenylthio)methyl)-indole-3-carboxilate (Ic)
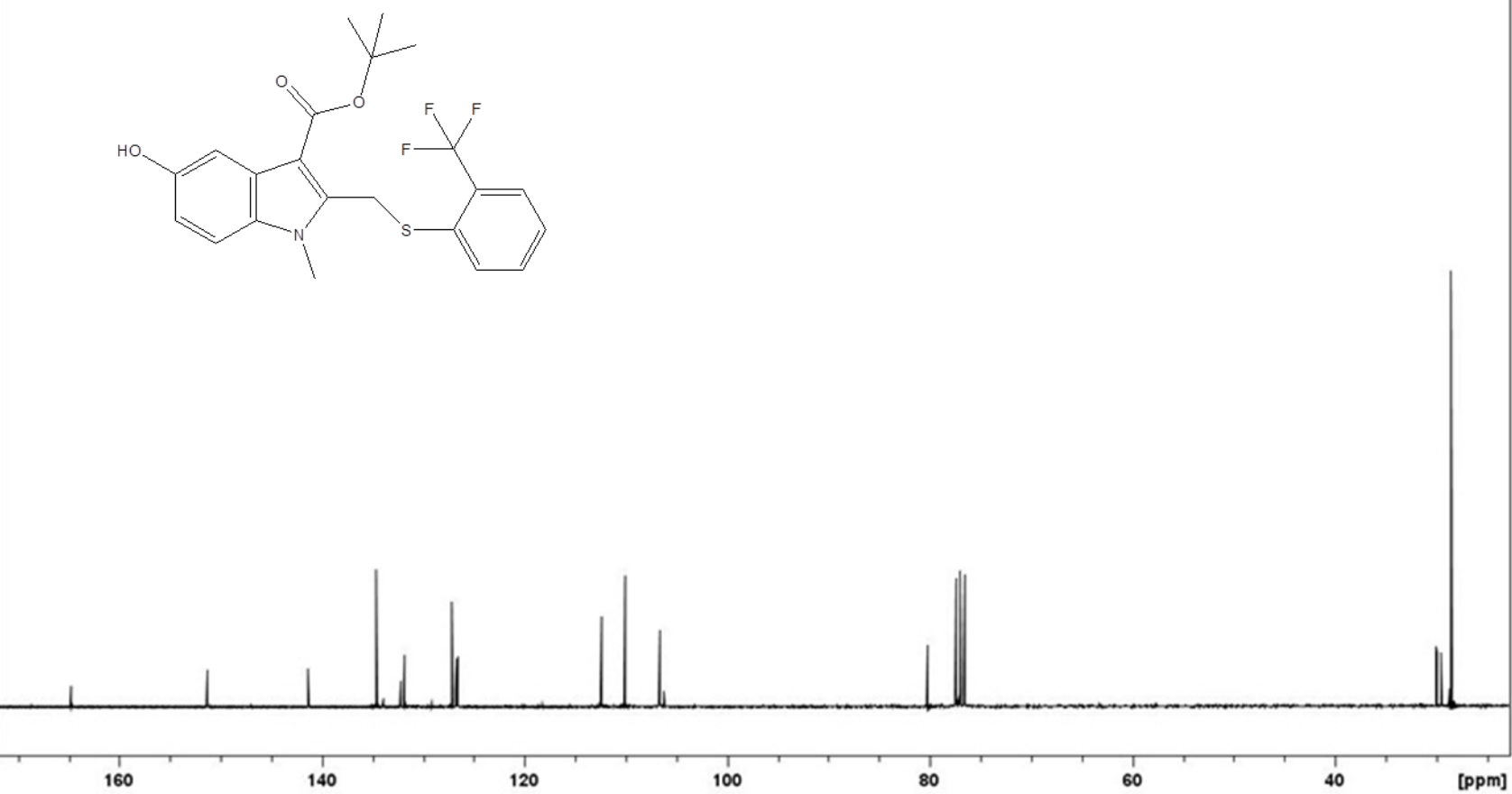


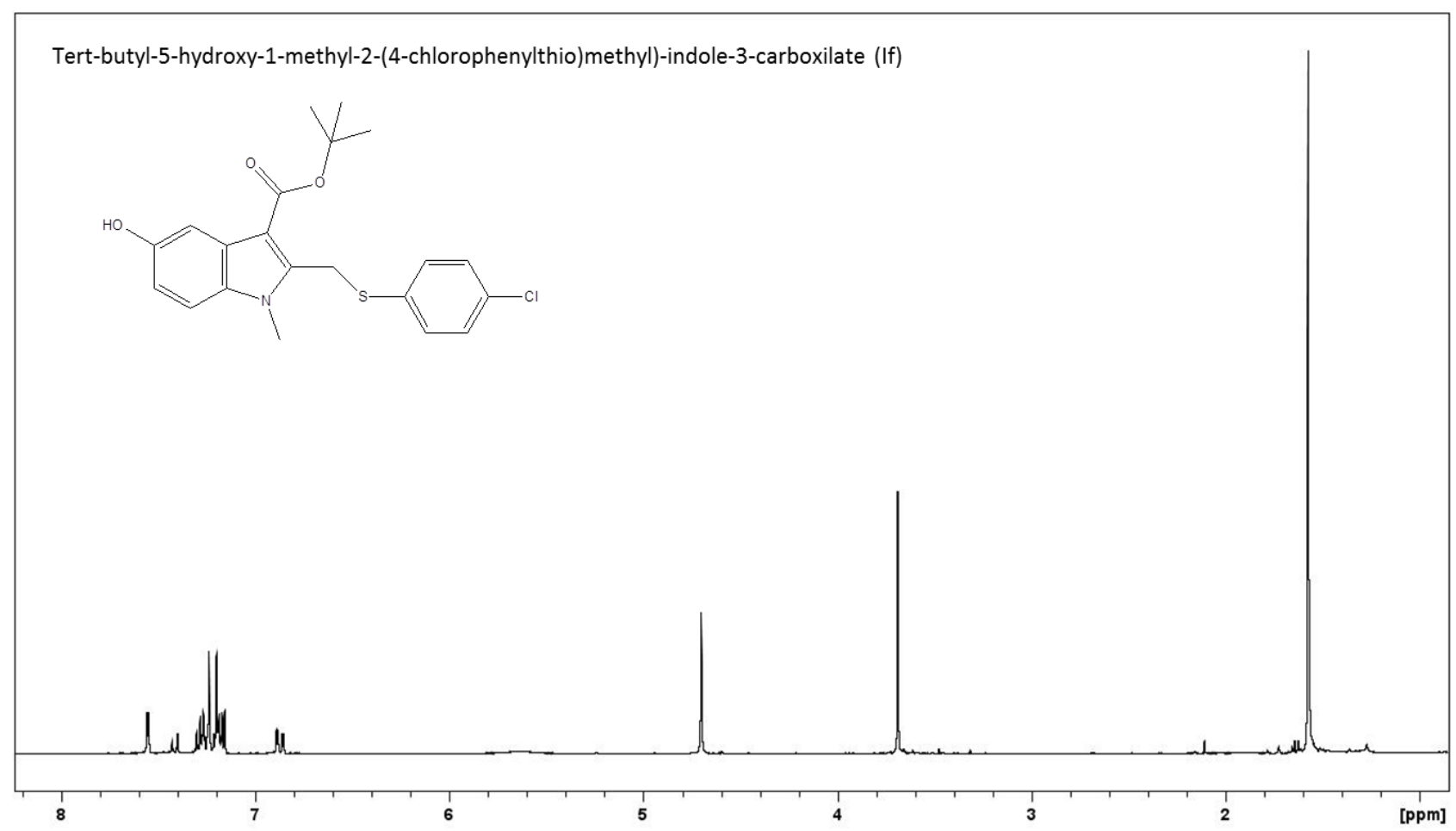


Tert-butyl-5-hydroxy-1-methyl-2-(4-chlorophenylthio)methyl)-indole-3-carboxilate (If)
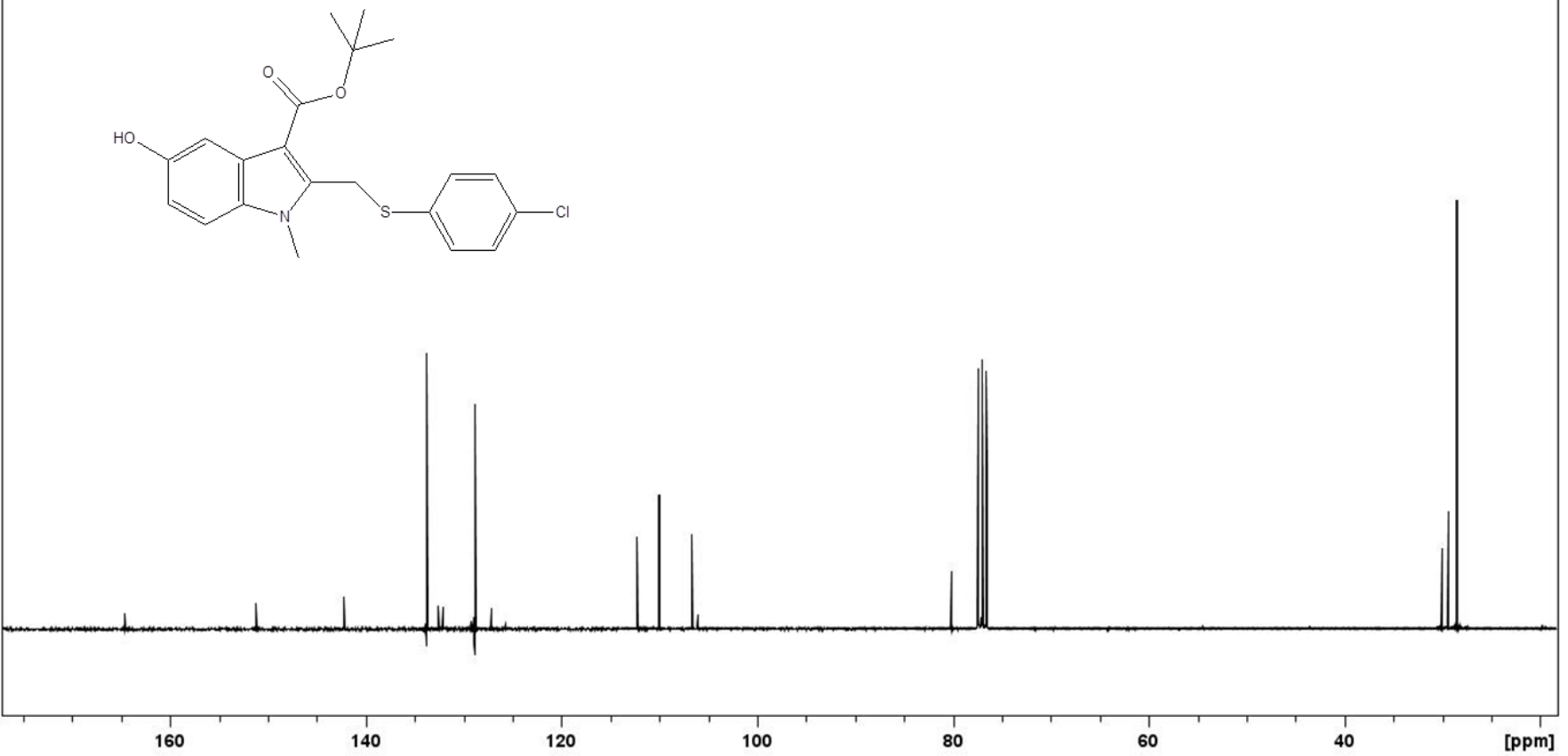

Tert-butyl-6-bromo-5-hydroxy-1-methyl-2-(2,6-dichlorophenylthio)methyl)-indole-3-carboxilate (Ig)
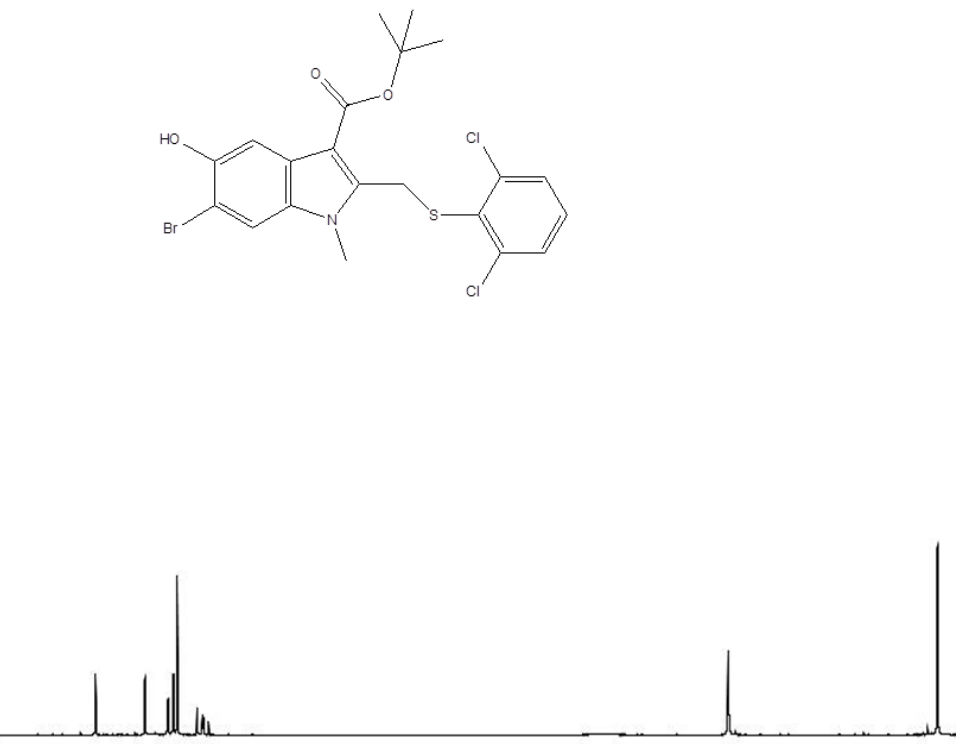

h 


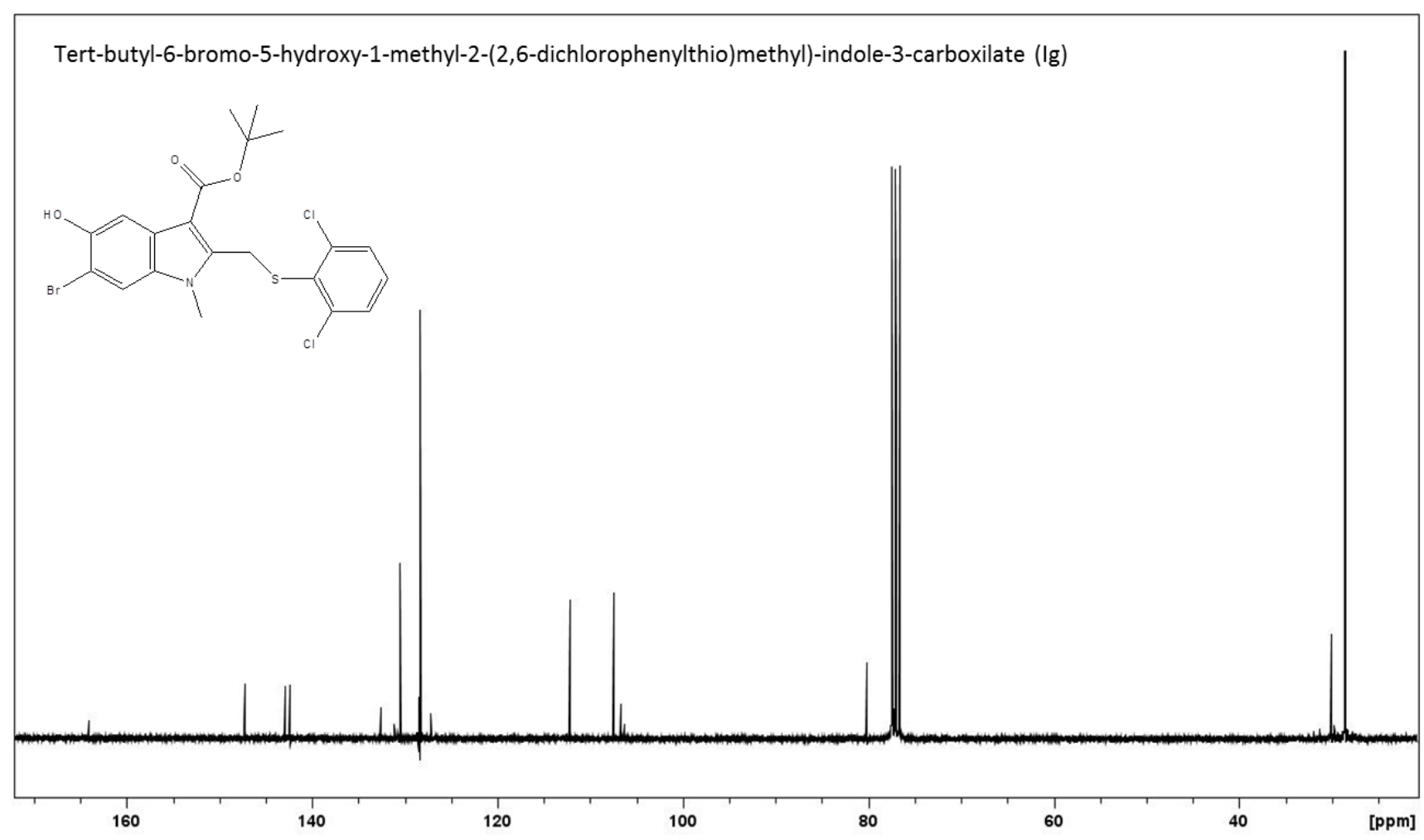




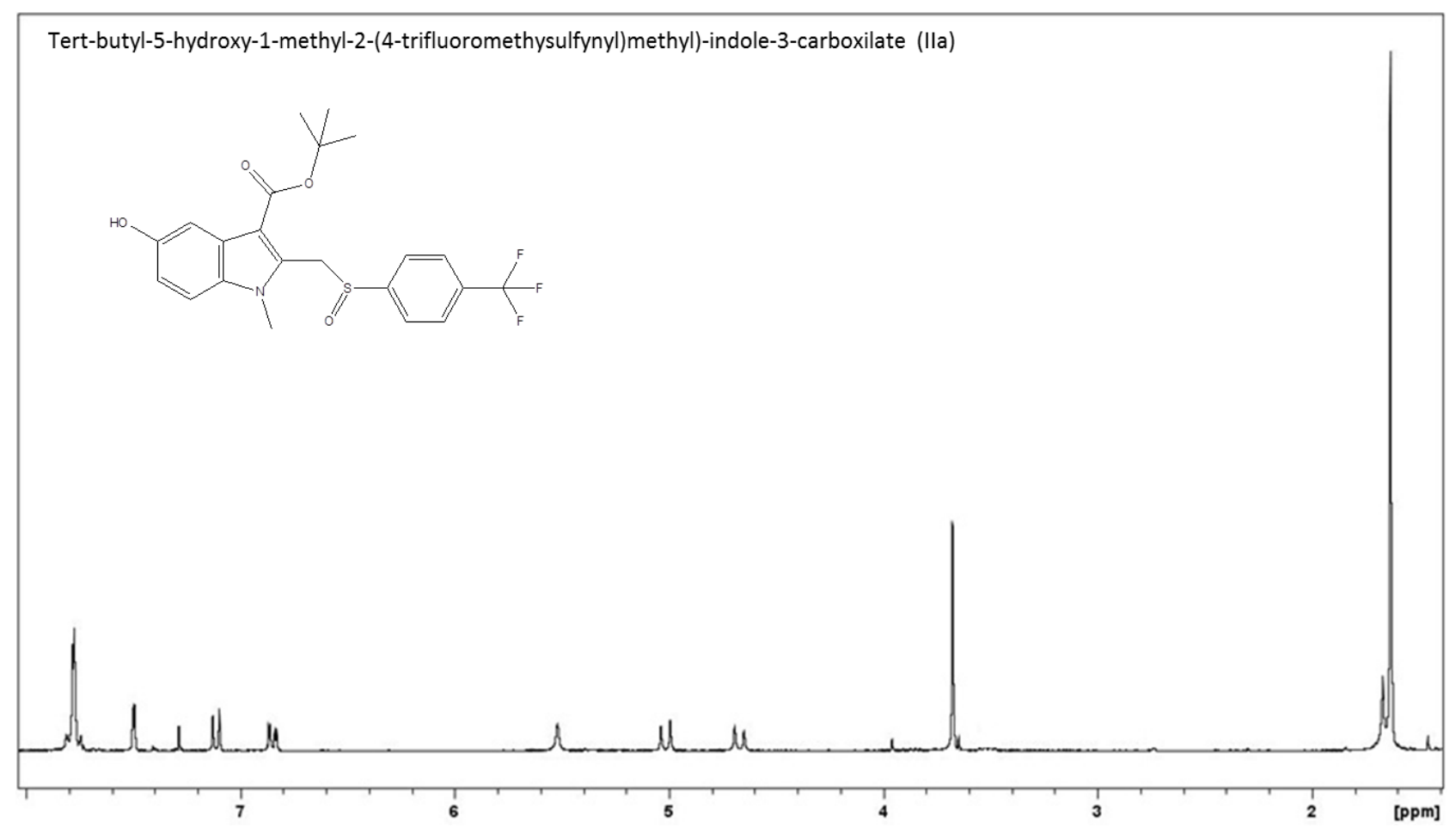

Tert-butyl-5-hydroxy-1-methyl-2-(4-trifluoromethysulfynyl)methyl)-indole-3-carboxilate (Ila)
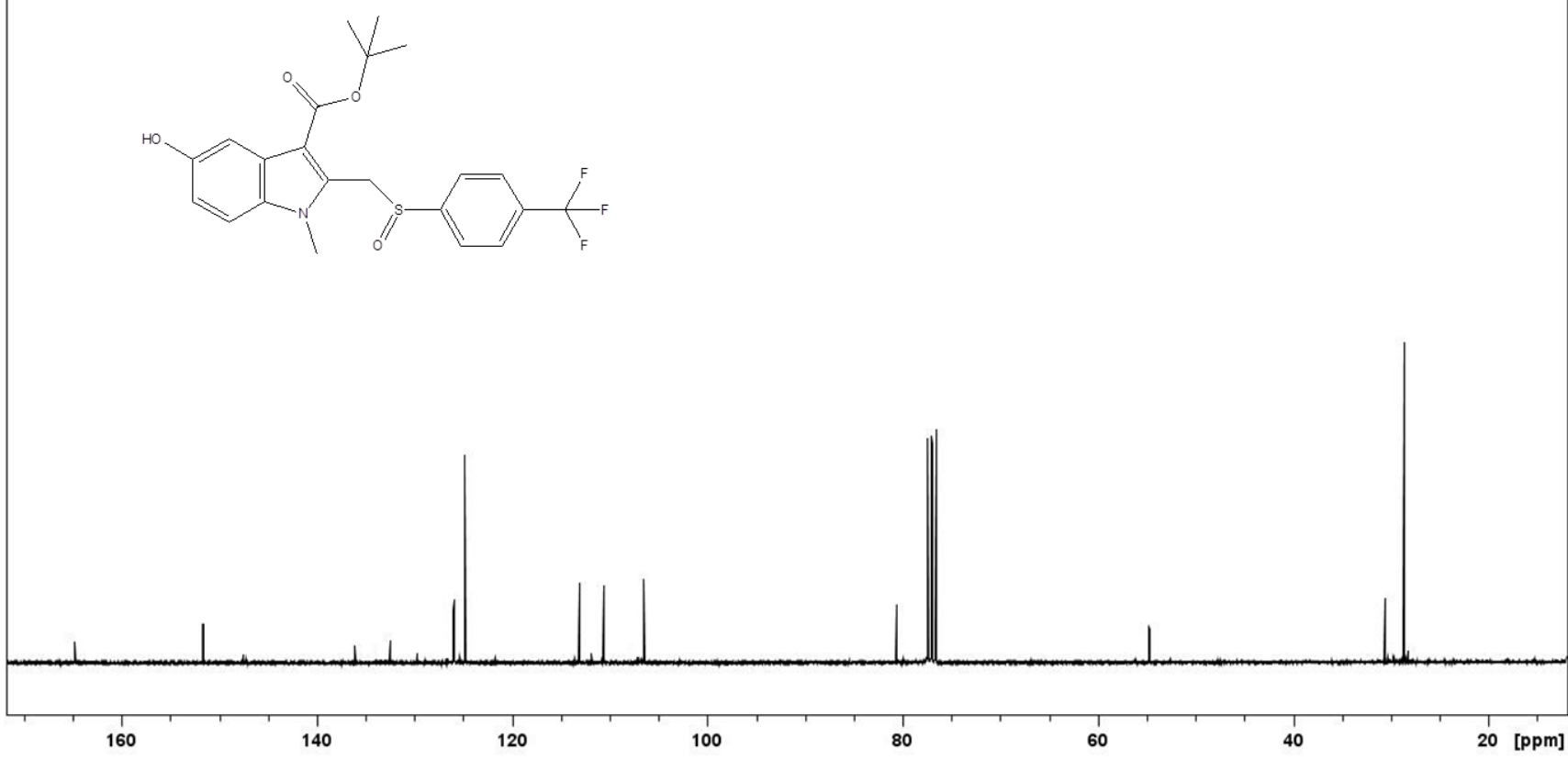


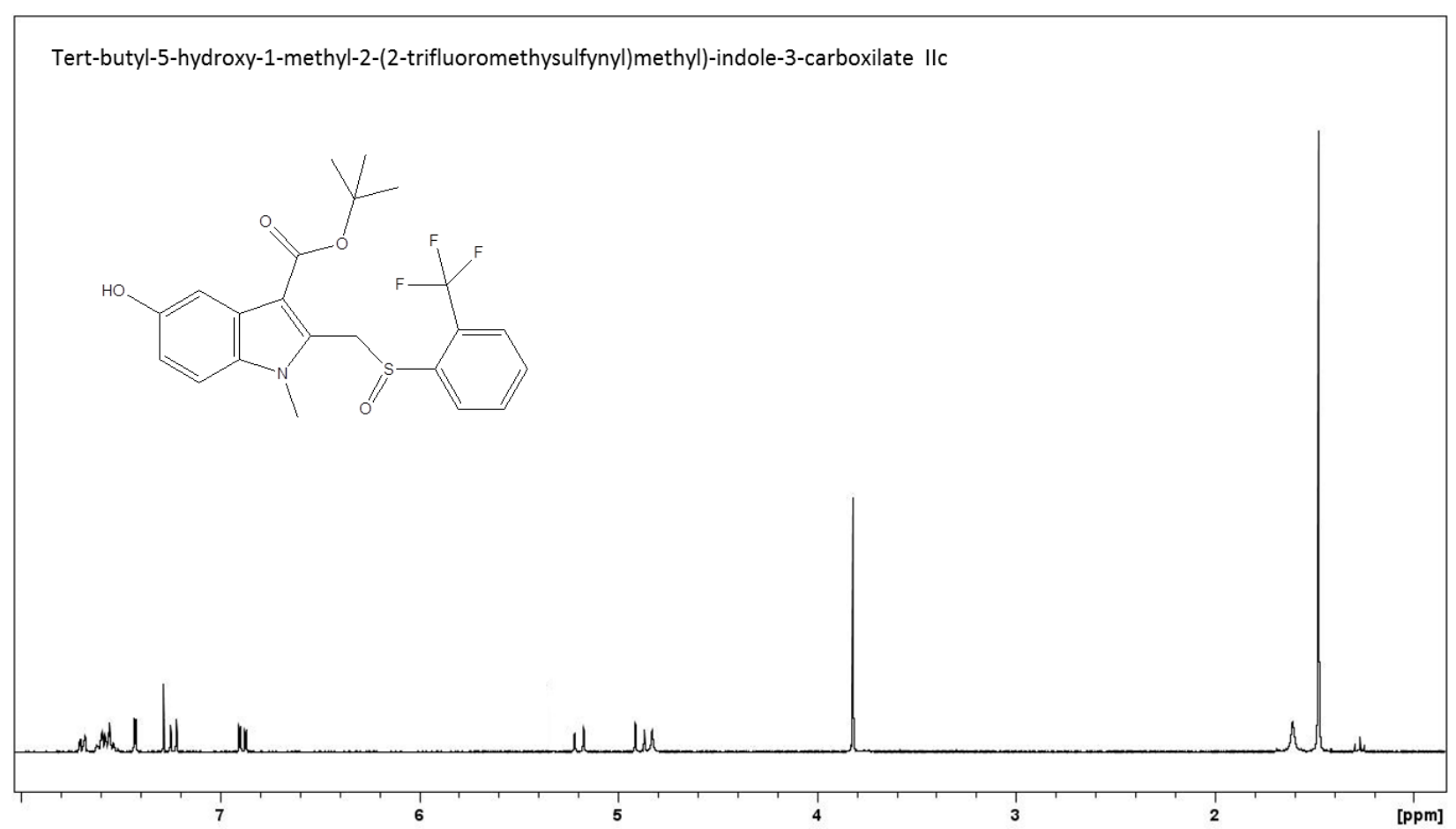




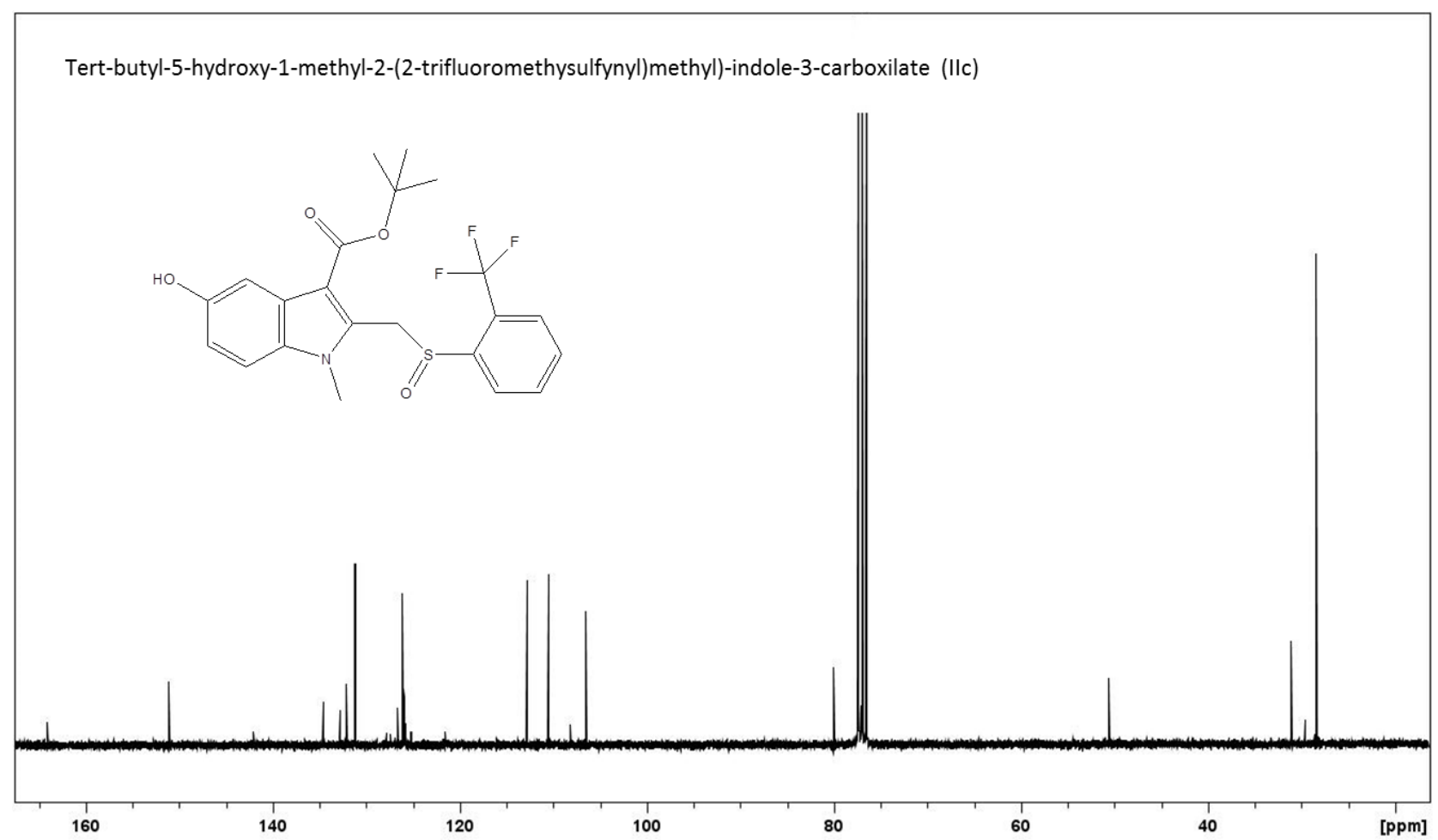

Tert-butyl-5-hydroxy-1-methyl-2-(4-fluorophenylsulfynyl)methyl)-indole-3-carboxilate Ile

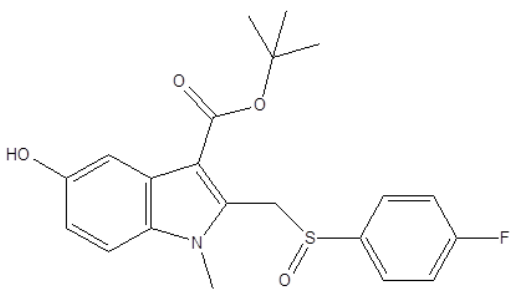

cumathen

ula 


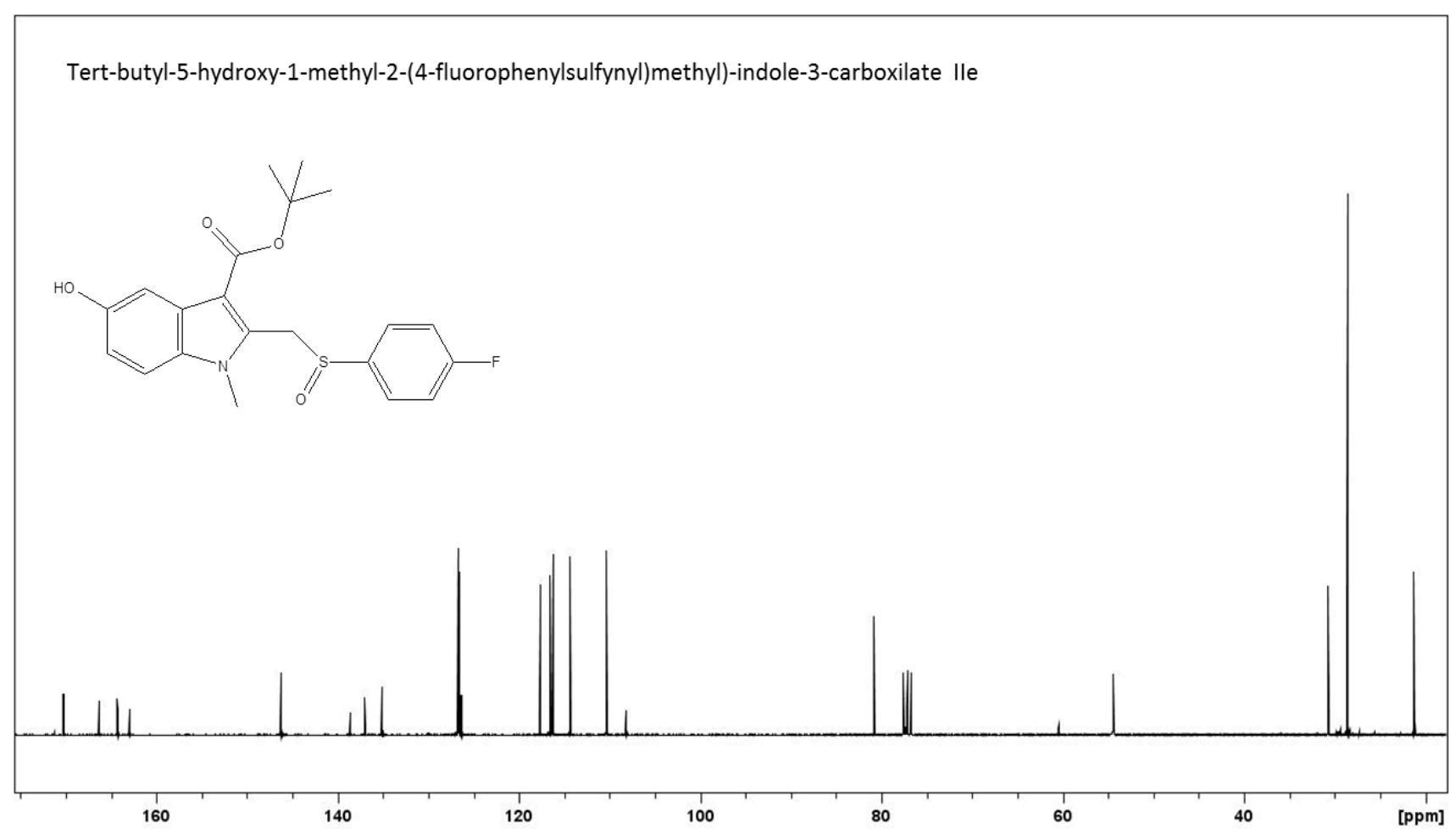




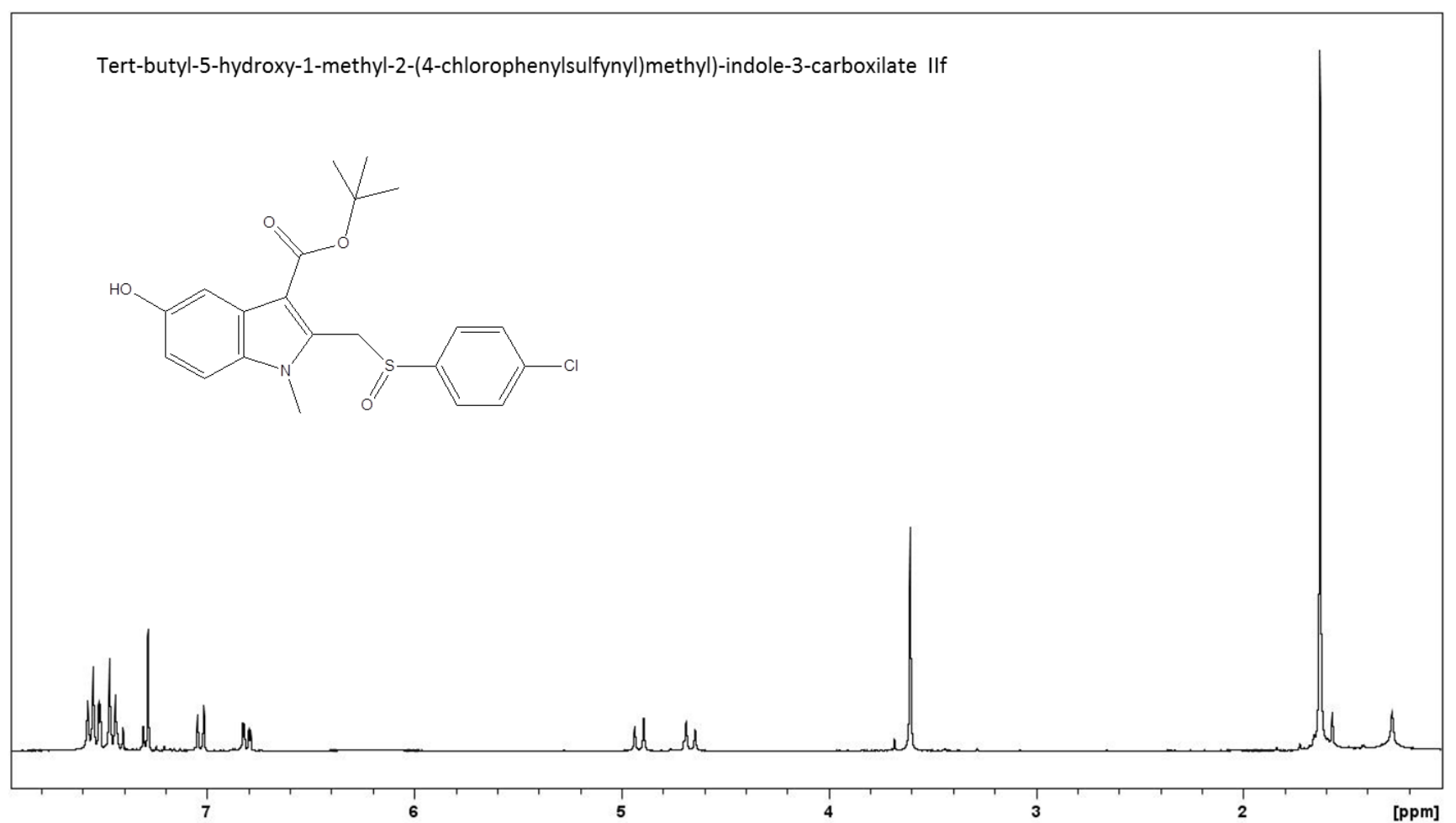

Tert-butyl-5-hydroxy-1-methyl-2-(4-chlorophenylsulfynyl)methyl)-indole-3-carboxilate IIf
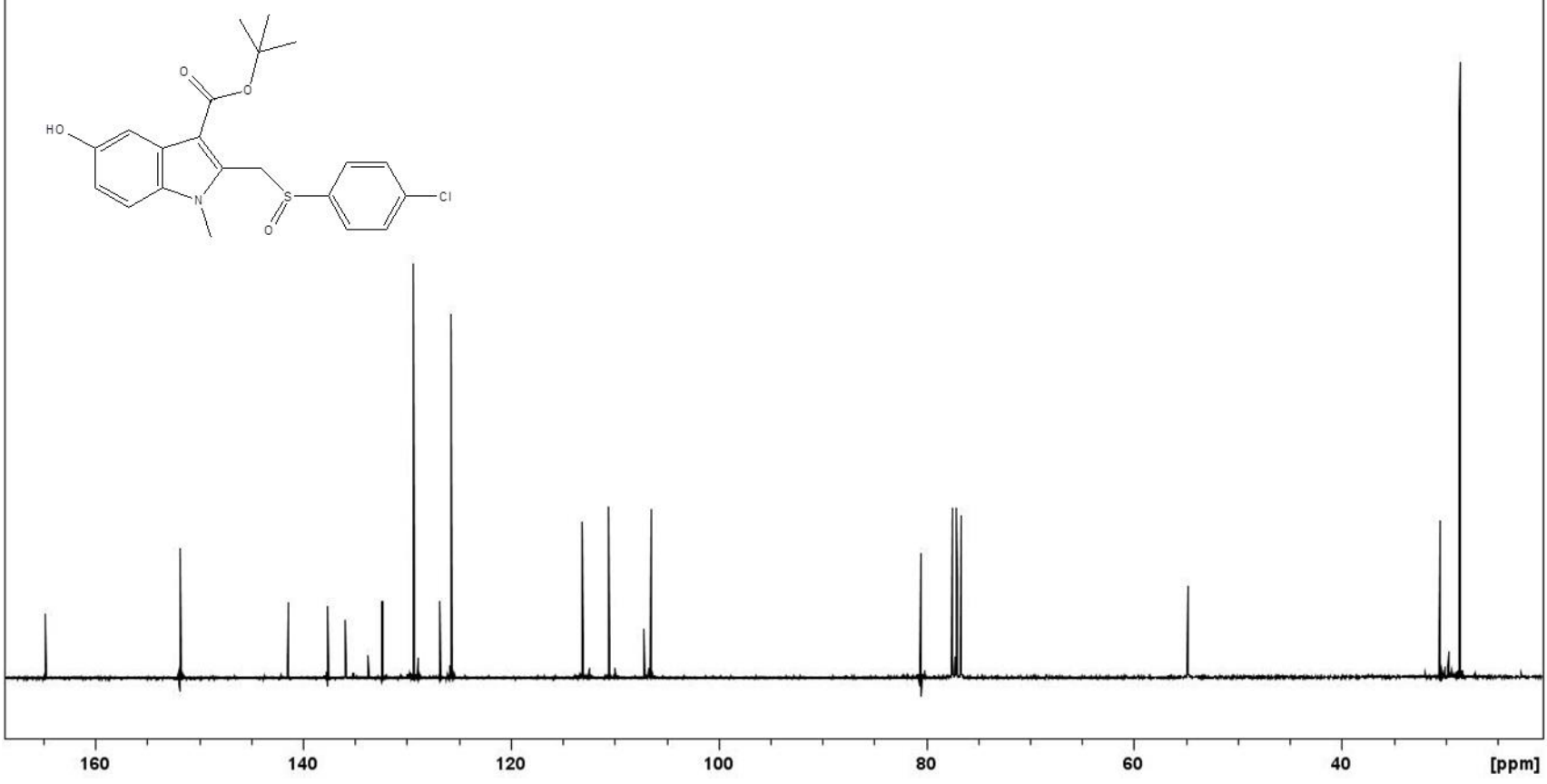
tert-butyl-2-((2,6-dichlorophenylsulfinyl)methyl)-6-bromo-4-((dimethylamino) methyl) -5-hydroxy -1-methyl-1H-indole-3-carboxylate IVa

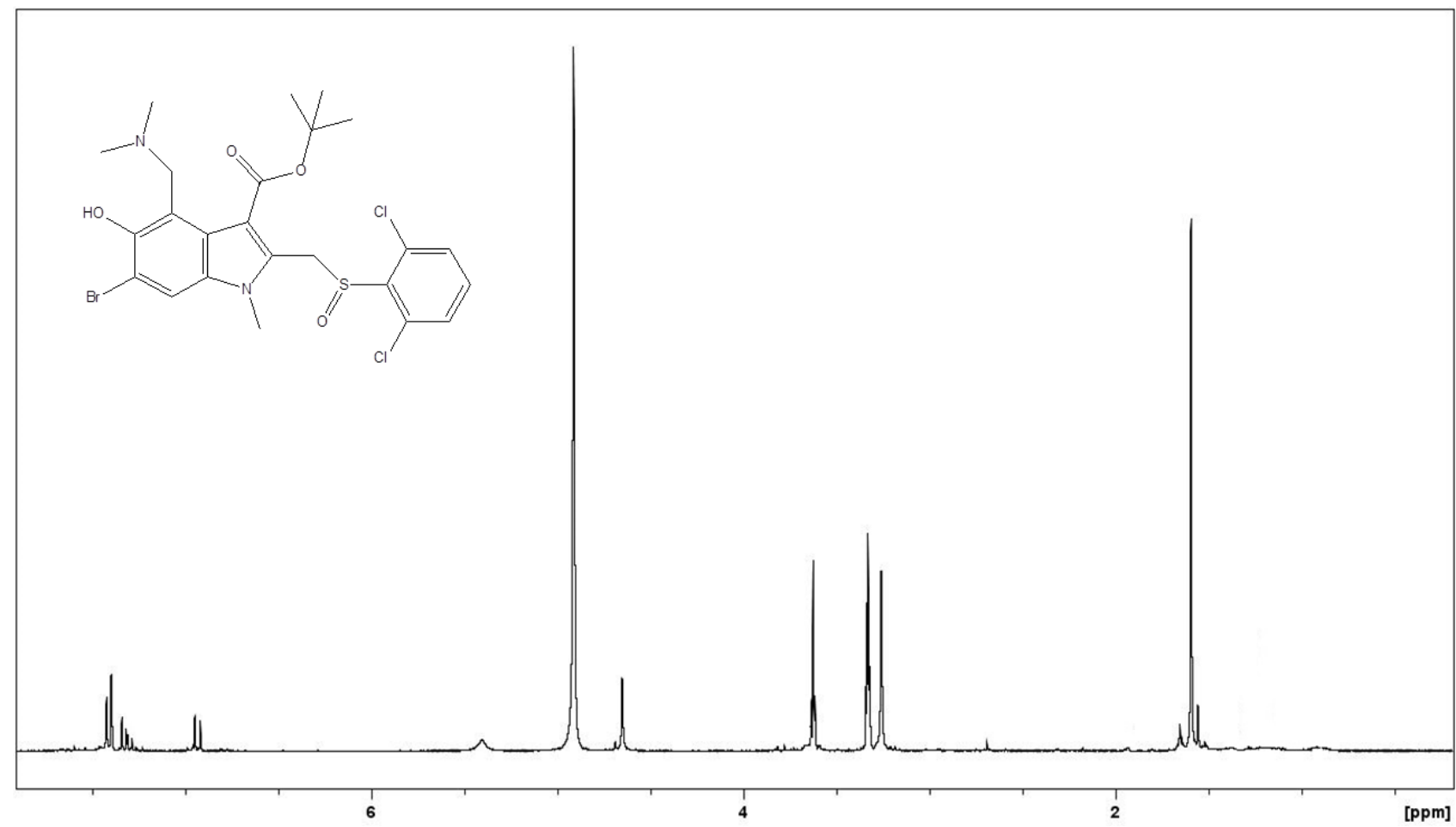

Tert-butyl-2-((2,6-dichlorophenylsulfinyl)methyl)-4-((dimethylamino)methyl)-5-hydroxy-1-methyl-1H-indole-3-carboxylate IVb
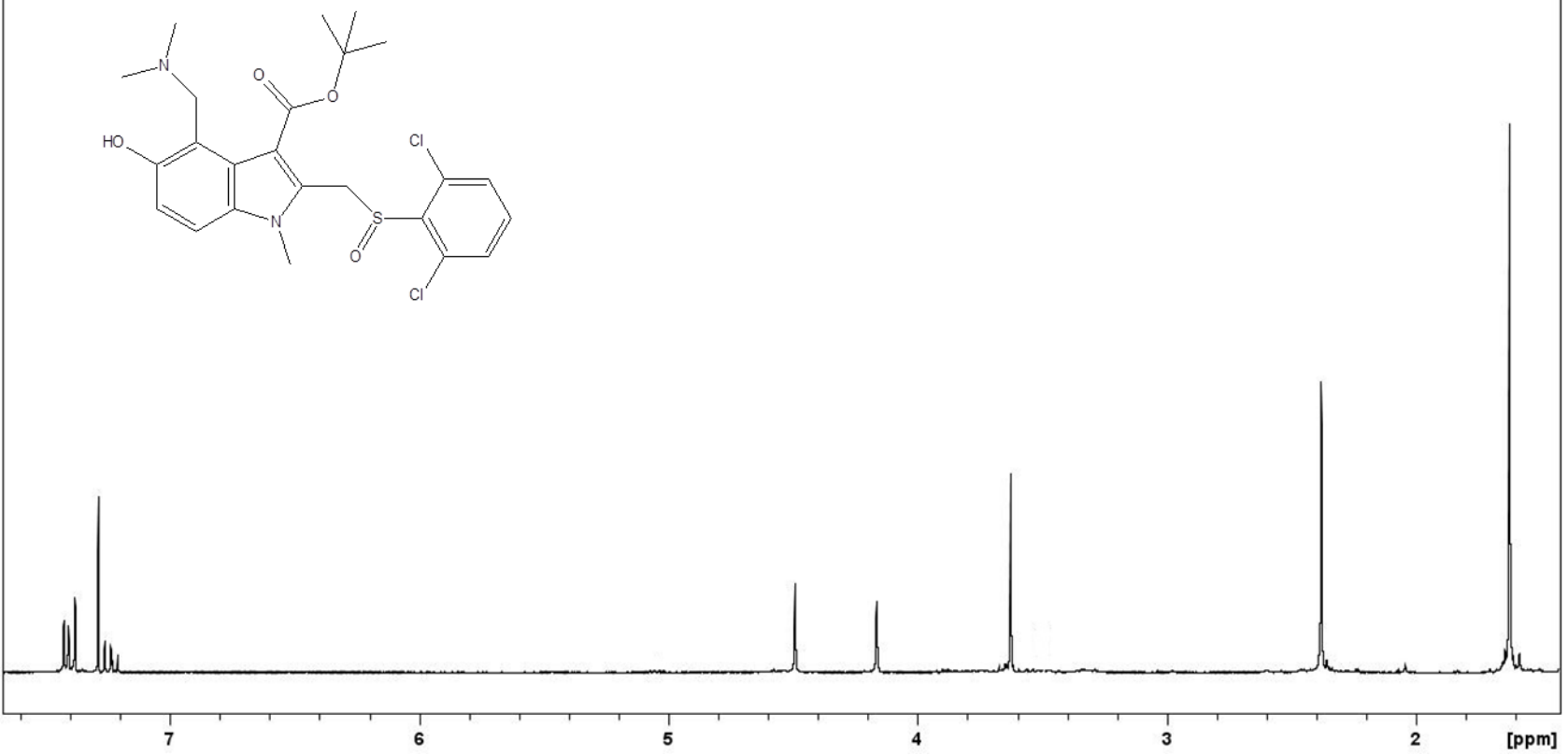
